\title{
Uncertainty, Task Environment, and Organization Design: An Empirical Investigation
}

\author{
Avner Ben-Ner \\ Fanmin Kong ${ }^{*}$ \\ Stéphanie Lluis
}

December 2011

\begin{abstract}
The paper addresses two broad research questions: 1. How do internal uncertainty associated with the task environment and external uncertainty arising from market volatility impact organization design? 2. What are the relationships among various elements of organization design: delegation of decision-making, incentives, monitoring, and internal labor market practices (promotion, training, employment security)? We expand on Prendergast (2002a), who challenged the conventional view of a tradeoff between risk and incentives, and build a single unified framework for answering our two research questions. Using a uniquely rich dataset that contains detailed information about the task environment of core employees and organization design at the individual, group and firms levels in 530 Minnesota firms in the mid 1990s, we first find support for Prendergast's key argument that internal uncertainty (over which employees have control) affects directly the allocation of decision-making and only indirectly incentives (via allocation of decision-making). This confirms similar findings by Foss and Laursen (2005), DeVaro and Kurtulus (2010) and Shi (2011). We also find that internal uncertainty has much impact on organization design through the choice of delegation of decision-making at the employee level, less so at the group level, and very little at the firm level, whereas external (market) uncertainty has little effect on organization design, especially at the individual and group level. Decision-making, monitoring, various internal labor market practices and incentives are strongly related to each other through substitution and complementarity.
\end{abstract}

Keywords: uncertainty, organization design, task complexity

Classification Codes: L20

*Industrial Relations Center, Carlson School of Management, University of Minnesota, $32119^{\text {th }}$ Avenue South, Minneapolis, MN 55455, USA, benne001@umn.edu

**Guanghua School of Management, Peking University, Beijing 100871, China, fkong@gsm.pku.edu.cn.

***University of Waterloo, Economics Department, 200 University West, Waterloo, ON N213G1, Canada, slluis@uwaterloo.ca. 


\section{Introduction}

Organization design is the combination of complementary and substitutable practices that a principal selects in order to direct and improve the effort of agents to pursue organizational objectives. For example, in a restaurant, management has to decide how much discretion to permit waiters regarding items not on the menu, whether to require them to pool tips or allow them to keep the tips they earn, how much training to provide, whether to supply promotion opportunities, and more. In a software firm, management has to choose how much discretion to allow engineers in the programming process and whether they will work in teams, how to compensate them, and so on. In a lawn-mower manufacturing plant, management has to choose between an assembly line where each worker is assigned a single function and teams that have collective responsibility to assemble mowers, etc.

The idea of complementarity in organization design practices has long been accepted (Miller, 1986, Milgrom and Roberts, 1992), and empirical work had generally confirmed the theoretical arguments, although with varied results depending on the approach used, the particular practices analyzed and their specific definition. ${ }^{1}$ Complementarities materialize in a system of complex interactions among multiple elements that depend on the organizational context (Ennen and Richter, 2010). The choice of the specific practices in a restaurant depends on the complexity of the menu, the degree of flexibility the restaurant wants to provide its clients, the desired level of service, etc. The choices of the manager in the lawn-mower plant are made in view of the constraints imposed by the technology of production and how many different types of mowers the plant produces.

\footnotetext{
${ }^{1}$ A substantial literature emerged analyzing the rapid growth in the use of "innovative" human resources management practices since the 1980s (practices aimed at increasing employee involvement in the firm's production and decision processes, studied inter alia by Osterman, 1994, 2000; Ichniowski, Shaw and Prennushi, 1997; Cappelli and Neumark, 2001) and the effectiveness of exploiting complementarities among various practices, such as combining incentive compensation with employee involvement and skill development (Huselid, 1995; Delaney and Huselid, 1996; Ichniowski et al., 1996; Ichniowski and Shaw, 2003; Laursen and Foss, 2003; Ben-Ner and Lluis, 2011). Some studies have demonstrated a significant positive link between delegation and incentives (MacLeod and Parent, 1999; Nagar, 2002). Other studies have examined the firm's choice between monitoring and pay and concluded that firms use efficiency wages as a substitute for monitoring (Neal, 1993; Rebitzer, 1995).
} 
In this paper we put forth a theoretical framework for analyzing the key elements of organization design in diverse settings, focusing on issues associated with the tasks of core employees such as waiters, software engineers and manufacturing workers. In particular, the task environment may create asymmetric information between core employees and their direct supervisors; asymmetric information creates opportunities for hidden action by employees and uncertainty about outcomes for supervisors. We identify elements of organization design that ameliorate the problems created by such uncertainty: delegation of decision-making, incentives, monitoring and internal labor market practices (employment security, training and promotions).

The nature and consequences of uncertainty (risk) in organizational contexts came under theoretical scrutiny by Zabojnik (1996), Prendergast (2002a), Baker and Jorgensen (2003) and Raith (2008). These authors analyzed the effect of uncertainty on the choice of actions by agents, distinguishing between uncertainty that is beyond agents' control and uncertainty that is related to agents' effort. $^{2}$ They showed that the relationship between uncertainty and incentives is not necessarily one of tradeoff: unlike uncertainty that is beyond the control of agents, uncertainty related to agents' effort is positively related to incentives because managers regard employees' unobservable actions as strategically uncertain and seek to influence these actions through incentives. Prendergast (2002a) identifies the complexity of workers' task environment as the source of such uncertainty and predicts that the more complex the task environment the greater will be the extent of delegation of decision-making and therefore the greater will be the reliance on incentives.

We use Prendergast's (2002a) framework as a platform for (1) understanding the relations among the various elements that comprise organization design and (2) analyzing the relationship between two measures of uncertainty - the task environment at the shopfloor level and income variability at the industry level - and organization design. The choice of organization design for waiters in a restaurant, engineers in a software shop and production workers in a manufacturing plant depends centrally on the nature of their tasks. Complex, variable and non-routine tasks require employees' knowledge of specific

\footnotetext{
${ }^{2}$ There are certain differences in the analytical frameworks of these authors and in their terminologies, some of which will be discussed in the next section. Rantakari (2008) reviews this literature and provides a detailed theoretical analysis of uncertainty and incentives.
} 
circumstances and ability to deal with problems as they emerge, and consultation among co-workers to address particularly complicated situations. In such task environments, supervisors have less immediate information and knowledge about the work of their employees and therefore face greater uncertainty about outcomes than in simpler task environments. This type of uncertainty may be called internal uncertainty because it originates at the workplace level. The greater is this uncertainty the greater will be the involvement of core employees in making decisions about how to plan and execute their tasks and whom to consult. Incentives, monitoring, internal labor markets, and more will be designed so as to support the allocation of decision-making.

The work of employees is affected by additional factors. For example, for waiters the main sources of external uncertainty are the preparation of food in the kitchen and variations in demand for restaurant dining; for software engineers, it is the demand for software, and for manufacturing workers it is the supply of parts and the demand for lawn mowers. The sources of external uncertainty are generally outside the control of these core employees, so managers need to find ways to deal with their impact.

Thanks to a uniquely rich dataset of a cross-section of 530 firms based and operating in Minnesota, we are able to explore empirically the importance of these sources of uncertainty for incentives and for the interplay between incentives, delegation of decision-making, monitoring and internal labor market practices. Our dataset contains rich survey information on delegation of decision-making to employees and teams, individual, group and firm-based performance-pay plans, monitoring and internal labor market practices (training, promotion from within and employment security provisions). We also have information on the volatility of income in a firm's industry as a measure of external uncertainty, and the complexity, variability and routine of core employees' tasks as an internal uncertainty measure.

We carry out our empirical analysis in two stages. First, we replicate existing empirical tests of Prendergast's main argument about the role of delegation of decisionmaking in the relationship between uncertainty and incentives. Second, we analyze the joint choice of delegation, monitoring, internal labor market practices and incentives in the presence of uncertainty. We find that internal uncertainty influences substantially organization design through the choice of the degree of delegation of decision-making to 
employees, and through elements that support its desirable application, namely monitoring, incentives and internal labor market practices. Uncertainty reflected by market volatility has a more limited effect on organization design. We also find that the various elements of organization design are significantly associated with each other in terms of complementarity and substitutability relationships at the three organizational levels.

The paper makes two principal contributions. First, we provide the first comprehensive analysis of several elements of organization design simultaneously in a single unified framework and, thanks to our unique dataset, we adduce empirical evidence on substitutability and complementarity relationships among delegation of decision-making, incentives, monitoring and internal labor market practices; we explore these relationships at the individual, group and firm levels.

Second, this is the first paper to empirically investigate in detail the role of the task environment in shaping organization design. The role of delegation in the relationship between risk and incentives has been tested empirically by Foss and Laursen (2005), Wulf (2007), DeVaro and Kurtulus (2010) and Shi (2011). These studies find positive correlations between their measures of risk and delegation and between delegation and incentives confirming the importance of the complementarity between delegation and incentives when analyzing the risk-incentives trade-off, and emphasizing the positive link between risk and delegation. However, the measures of uncertainty used originate outside the firm, whereas the task environment reflects uncertainty that is internal to the firm and is under the influence of employees. Moreover, our two measures of uncertainty, one internal linked to the task environment and another external linked to market volatility, allow us to perform a clean test of the relationship between uncertainty, incentives and delegation as discussed by Prendergast (2002a) and Raith (2008).

The paper proceeds as follows. Section 2 summarizes the theoretical literature. Section 3 describes the data and empirical strategy. Section 4 presents the results, and Section 5 concludes the paper.

\section{Conceptual Framework and Hypotheses}


In this section we develop a brief conceptual framework, building on Prendergast (2002a) and applying it to the context of core employees' task environment. We develop hypotheses regarding the links between uncertainty, incentives and delegation, following Foss and Laursen, (2005) and DeVaro and Kurtulus (2010), who tested these relationships using alternative measures of these concepts. We then extend the model by integrating additional elements of organization design, monitoring and internal labor market practices, and generate hypotheses regarding the relationship between these elements and internal uncertainty, as well as among the various elements of organization design. We emphasize the task environment of core employees as the source of internal uncertainty as well as the interaction among various elements of organization design.

The need for organization design arises because managers cannot make all decisions themselves and because they cannot expect that their employees will enact them flawlessly. Agents have local specific information and knowledge that principals cannot obtain costlessly. Consequently, managers-principals (1) must delegate some decision-making and invest in means that help direct the effort of employees-agents towards organizational objectives, or (2) invest in the reduction of asymmetric information. The primacy of delegation is articulated from different perspectives by Marschak and Radner (1972), Hart and Moore (1990), Ben-Ner et al. (1993), and Prendergast (2002a). ${ }^{3}$

\subsection{The task environment and uncertainty}

Jobs are designed for efficiency relative to organizations' business strategy, technology, workforce, and labor and product market conditions (Lindbeck and Snower, 2000; Zoghi et al., 2005). The nature of the tasks associated with a job affects employees' ability to make good decisions, the information they have about the association between their efforts and results, and the information supervisors have about what employees do and how hard they work. A characterization of tasks that is particularly relevant to the

\footnotetext{
${ }^{3}$ In standard agency models the need for delegation is assumed, often implicitly, with the emphasis being laid on the need to support delegation with incentives.
} 
understanding of organization design and uncertainty considers how simple or complex, stable or variable, and routine or non-routine tasks are. ${ }^{4}$

Task complexity. The execution of complex tasks requires more skillful, thoughtful and experienced decision-making, and is more prone to errors than the execution of simple tasks. For example, the task of solving a system of nonlinear equations is more complex than the task of solving for $x$ in $3 x=6$; the task of extracting a tumor from a brain cavity is more complex than the task of extracting a splinter from a finger; the task of serving a customer in a fast-food restaurant is simpler than the task of serving a demanding customer in an expensive restaurant; and the task of writing a report about local crime statistics is simpler than the task of analyzing the reasons for changes in the incidence of local crimes. Task complexity affects the information sets of both employees and their supervisors. The employee who carries out a complex task is in a better position than a supervisor to determine the specific demands of a particular situation, and how various factors (such as the multifaceted efforts of the employee and of other employees and managers, equipment, and the quality of materials) combine to determine the outcome of the execution of the task. The employee could, in principle, transmit his information to the supervisor so that she could make the key decisions for the employee, but the lack of reliability of transmission of information increases with the complexity of the tasks, as does the possibility of self-interested manipulation of the information. Although the employee has better information than the supervisor, he too suffers from uncertainty regarding the possible outcomes of his complex tasks.

Task variability. Task variability refers to the range of tasks and number of tasks an employee has to conduct. Tasks may remain unchanged for certain periods of time, as is the case of an assembly line where a worker installs windows, or may be moderately variable in the case of a bank teller who works with patrons with different needs, and even more variable for a general dentist. The greater the variability of a task the more careful, skilled and experienced an employee must be in order to execute the task faithfully, and the less effectively can a supervisor observe the quality of the execution of different dimensions of the task (unless more time is invested in monitoring).

\footnotetext{
${ }^{4}$ See Grandori (1991), March and Simon (1993), Autor et al., (2003), Manning (2005) and especially Perrow (1986).
} 
Task routine. The incidence of exceptions in the execution of tasks is captured by the third attribute of tasks, routine. The tasks of an assembly line worker, bank teller and general dentist are routine (although they differ in the degrees of complexity and variability), whereas the tasks of a researcher and of a developer of new electronic games are non-routine. Routine tasks are easier to execute and are easier to observe by a supervisor than non-routine tasks.

Henceforth we will refer to the difficulty of the task environment as a way to capture the combined effects of more complex, variable, and non-routine tasks. We have established that the greater the difficulty of the task environment the greater the uncertainty it creates for supervisors because of the factors that are beyond their control but are under the control of employees. A more difficult task environment also contains elements that are beyond the control of employees, so it entails greater uncertainty for employees - but less than for their supervisors. We will refer to the difficulty of the task environment as internal uncertainty. ${ }^{5}$ Our measure of internal uncertainty closely matches Prendergast's notion of job complexity. ${ }^{6}$ The difficulty of the task environment can be viewed as a type of respondable risk, a risk that the agent can respond to by exerting effort to collect information about the underlying state to make correct decisions (Shi, 2011). Our measure of internal uncertainty is also comparable to technological uncertainty about the productivity of the agent's effort because the agent has private information (specific knowledge) that is too costly to communicate to the principal (Raith, 2008), to ex-ante uncertainty for which the worker can observe part of its realization prior to making a decision or exerting effort (Zabojnik, 1996) and to volatility, a type of uncertainty whose realization changes the agent's optimal choice of action (Baker and Jorgenson, 2003).

In contrast, the factors that are beyond the control of both supervisors and workers cause what we will term external uncertainty; these factors include variations in the

\footnotetext{
${ }^{5}$ Prendergast (2002a) defines risk as uncertainty coming from the variance in the task environment. In his model, output from exerting effort on task $i$ depends on the effort level and on a random variable $\rho_{i}\left(y_{i}=e_{i}\right.$ $\left.+\rho_{i}\right)$. He assumes that while agents know the true values of $\rho_{i}$, the principal only knows the distribution of $\rho_{i}$. Uncertainty is defined as the variance $\sigma^{2}$ of the distribution of $\rho_{i}$.

${ }^{6}$ Job complexity is defined by Prendergast in the section describing his model's applications and extensions as an increase in the number of tasks on which the agent has to exert effort.
} 
performance of equipment that is not affected by employees' behavior, the behavior of other organizational units, and the market.

\subsection{Incentives and uncertainty}

Research on organization design has a long history in economics, hailing from diverse traditions and theoretical perspectives (Putterman and Kroszner, 1996). Common to the various approaches is that uncertainty has a central role in determining organization design. In agency theory, employees are compensated for their contracted effort, if that is costlessly observable. However, under conditions of asymmetric information regarding their effort, employees will be rewarded instead for their observable performance. Rewarding performance would be equivalent to rewarding input, unless there is some uncertainty or risk that affects performance and is beyond the control of employees. This noise in the measurement of employees' performance reduces the reliance on pay-for-performance (incentives) in the commonly-assumed case of riskaverse workers. This is the familiar tradeoff between risk and incentives.

Greater difficulty of the task environment creates greater asymmetric information between supervisors and employees (it is exactly the same as asymmetric information between principals and agents). Asymmetric information associated with agents' local specific and specialized knowledge calls for delegation of decision-making to the agents, but to encourage decision-making in the interest of the organization, incentives will be offered (Prendergast, 2002a). ${ }^{7}$ On the other hand, reliance on incentives will be negatively affected by risk and uncertainty that are beyond the control of risk-averse workers; this is a central tenet of economic theory. This type of uncertainty is not defined in Prendergast's model because agents are risk neutral. ${ }^{8}$ It can however be compared to the notion of environmental uncertainty defined in Raith (2008), a noise in the measure of the agent's output in a context in which agents are risk neutral but are protected by

\footnotetext{
${ }^{7}$ This is a point that originates with Grossman and Hart's (1986) theory, and has been emphasized by several authors (e.g., Tyson and Levine, 1990; Ben-Ner and Jones, 1995).

${ }^{8}$ It is typically defined as an additive exogenous shock $\varepsilon_{i} \sim N\left(0, \sigma_{\varepsilon}^{2}\right)$ in the output equation where $\sigma_{\varepsilon}^{2}$ represent external uncertainty (Rantakari, 2008).
} 
limited liability. Environmental risk does not affect the true productivity of the agent's effort but reduces the responsiveness of measured performance to the agent's effort. ${ }^{9}$

In sum, the task environment creates uncertainty for management and the desire to delegate some decision-making to employees and offer incentives. The first hypothesis derived from the above discussion is:

Hypothesis HA1: Internal uncertainty associated with the task environment is positively correlated with the use of delegation of decision-making and with incentives.

Regarding the relationship between internal uncertainty and incentives at various levels, because it is measured at the level of individual employees (rather than units or the firm level) its impact should be strongest on individual incentives, as individual core employees' outcomes are directly impacted by their task environment. If the nature of the task environment also affects the way groups produce their outcomes (because of the need to consult, for example), then greater internal uncertainty will beget also stronger group incentives. Generally, the impact of the individual core employees' task environment on firm outcomes should dissipate in firms with more than a few employees.

External uncertainty will be associated with less use of incentives if employees are risk averse. Theoretically, external uncertainty is assumed to be a source of exogenous risk that is uncorrelated with internal uncertainty. In reality, these two sources of risk might be correlated and it may be difficult to obtain a measure of external uncertainty that is purely exogenous. Whether incentives ought to be negatively or positively related to a certain source of uncertainty depends on how important responses to that risk are (Raith 2008). We return to this point in the data section where we present our empirical measures of uncertainty.

Incentives, if they are used at all, may be proffered at the individual, group or firm levels. Individual incentives aim to motivate individuals to engage desirable effort in situations where the individual has direct control over personal outcomes. Group

\footnotetext{
${ }^{9}$ Raith's model distinguishes explicitly between uncertainty that affects the agent's optimal choices and increases the value of his or her specific knowledge, implying greater use of incentives, and uncertainty in the measurement of performance commonly described in standard agency models, which predicts a tradeoff between risk and incentives.
} 
incentives aim to link the effort of group members when there is interdependence among their tasks and are tied to group outcomes. Firm incentives seek to align interests across individuals and units of a firm and are usually based on financial outcomes, particularly profit. If, as is the case in our empirical work, external uncertainty is measured at the industry level (thus not capturing much uncertainty associated with equipment reliability and the actions of other members and units of the organization), then it should not be linked to outcomes affected by individual employees and groups, that is, there should be no correlation between individual and group incentives and external uncertainty. ${ }^{10}$

We can now formulate hypotheses on the relationship between internal and external uncertainty and incentives at the individual, group and firm levels.

Hypothesis HA2: The correlation between internal uncertainty and incentives is positive and is stronger at the individual level than at the group and firm levels.

Hypothesis HA3: The correlation between external uncertainty and incentives is negative and is stronger at the firm level than at the individual and group levels.

The next three hypotheses summarize Prendergast's core argument about the link between risk and incentives; these are variants of hypotheses presented by Foss and Laursen (2005) and DeVaro and Kurtulus (2010) who each used different measures of uncertainty. ${ }^{11}$

Hypothesis HB1: $\quad$ Incentives and delegation of decision-making are positively correlated.

\footnotetext{
${ }^{10}$ An exception will occur in cases when core employees, such as wait staff in restaurants, and certain groups, such as teams of software engineers who generate programs, interact directly with the market. ${ }^{11}$ Foss and Laursen (2005) define environmental uncertainty and measure it using three variables: (i) the extent to which firms are innovative, (ii) the perceived increase in the level of competition and (iii) within industry variance in profitability. DeVaro and Kurtulus (2010) define market risk and measure it with a dummy variable equal to 1 if the current state of the market for the main product or service of the establishment is described as turbulent and $=0$ otherwise.
} 
Hypothesis HB2: The correlation between internal uncertainty and incentives decreases when delegation of decision-making is taken into account.

Hypothesis HB3: The correlation between external uncertainty and incentives decreases when delegation of decision-making is taken into account.

\subsection{Organization design practices and uncertainty}

The use of incentives is restricted by their direct cost, the cost of the risk they impose on employees and the cost of dysfunctional behavior they sometimes cause (Prendergast, 1999). Consequently, additional practices that substitute for incentives or complement them to make them more effective are often implemented (Holmstrom and Milgrom, 1994; Milgrom and Roberts, 1995; Prendergast, 1999). Such practices include monitoring and internal labor markets (e.g., training, promotion-from-within and employment security). Ichniowski and Shaw (2003) review the literature on complementary human resource management practices and find evidence that a broad range of complementary practices enhances performance more than a more restricted one. In a similar vein, Ennen and Richter (2010) conclude from their review of the literature that "complementarities may only become fully effective when embedded in an overall system involving many elements." They also point to the paucity of studies that take the environment into account when examining complementarities among practices.

Our general framework, building on Prendergast's model, does just that: it incorporates the role of internal task environment and the external market and includes monitoring and several internal labor market (ILM) practices, in addition to delegation of decision-making and incentives. Our first observation is technical: the inclusion of additional practices (ILM and monitoring) in the equation that explains the prevalence of incentives in the face of uncertainty will change the measured association between delegation and incentives. As in a typical omitted variables bias context, the sign of the bias depends on the sign of the association of the ILM practices and monitoring with delegation and with incentives, about which we hypothesize later. 
Hypothesis HC1: The correlation between delegation of decision-making and incentives changes after the inclusion of ILM practices and monitoring to the equation that explains incentives.

Monitoring refers to the collection of information about signals of worker effort that complements or substitutes for incentives. ${ }^{12}$ Monitoring is less likely to be employed in uncertain task environments because it is difficult for supervisors to identify what employees should be doing (Prendergast 2002a, 2002b). Therefore:

Hypothesis HC2: Internal uncertainty is negatively correlated with the use of monitoring.

Internal labor markets consist of a set of practices oriented to the long run: on-thejob training, promotion-from-within, employment security, and so on. On-the-job training encourages firm-specific skill development; promotion-from-within provides returns to sustained good performance, desirable behaviors, trustworthiness and favorable disposition; and employment security safeguards employees' returns against employer opportunism (Baron and Kreps, 2000; Milgrom and Roberts, 1992). These practices are most desirable when the task environment creates internal uncertainty that cannot be satisfactorily addressed in the short run. When the task environment creates long-term uncertainty, incentive practices tying performance to short-run outcomes (such as bonuses) would not be as effective as incentives based on long-term objectives such as promotions and training, which offer permanent pay increase opportunities, and employment security. Therefore:

Hypothesis HC3: $\quad$ Internal uncertainty is positively associated with ILM (training, promotion-from-within and employment security).

\footnotetext{
${ }^{12}$ Monitoring comes in many varieties: it may be exercised continuously or at fixed or random intervals, and may be carried out by direct supervisors, coworkers, others with whom a worker has periodic or occasional contact (such as customers and trainers), or equipment (such as keyboard stroke counters and surveillance cameras).
} 
ILM practices complement the use of delegation of decision-making. The complementarity between ILM practices associated with training, promotion from within and employment security and practices associated with decentralization has been hypothesized and empirically identified in the literature (MacDuffie, 1995, Ichniowski et al., 1997, Laursen and Foss, 2003). Training increases the benefits of delegation of decision-making because it helps employees to be more effective and generate valuable ideas (Autor, Levy and Murnane, 2003), and employment security and promotions offer future benefits in return for greater employee effort associated with delegation of decision-making (Aoki, 1988). Training contributes to the enhancement of employee skills, and promotion opportunities and employment security help motivate them as the effectiveness of skilled and motivated employees cannot be fully achieved if the workers are not involved in what needs to be done and how it should be performed. This leads to the following hypothesis:

Hypothesis HC4: Delegation of decision-making and ILM practices are positively correlated.

The relationships between incentives and monitoring and between delegation and monitoring are ambiguous. The "monitoring intensity" principle states that improving information gathering can be profitable when incentive intensity is high and therefore information is more valuable (Milgrom and Roberts, 1992). In contrast, the efficiencywage literature emphasizes the tradeoff between incentives and monitoring arising from their relative (marginal) costs. Prendergast (2002a) contrasts input monitoring with output-based pay and delegation, suggesting that monitoring and incentives and delegation might be substitutable practices, especially in unstable environments. Whether an organization will use monitoring to complement or substitute for incentives and delegation depends on many details specific to the organization's task environment and other circumstances. ${ }^{13}$

\footnotetext{
${ }^{13}$ For example, Demougin and Fluet (2001) show that the extent of complementarity or substitution between incentives and monitoring depends on the level of informational rents enjoyed by workers and their liability limits (their ability to post bonds and the firm's ability to levy fines on workers), and characteristics of the monitoring system (the cost of increasing the precision of information and the
} 
ILM practices may be used in task environments where monitoring is particularly difficult or costly and where incentives are very expensive or difficult to administer because of unobservability of individual output. ${ }^{14}$ ILM practices such as promotion-fromwithin constitute also long-term incentives, so they may partially substitute for short-term incentives. Thus firms rely on monitoring of inputs and outputs to ensure that workers act correctly (e.g., Hart and Moore, 2005; Garicano, 2000), and on ILM practices to provide long-term incentives, accumulate firm-specific knowledge, aid in the collection of information about worker behavior, and contend with issues of ex post hold-up problems associated with various incentive contracts (e.g., MacLeod and Carmichael, 2000). This suggests that ILM practices might substitute for incentives. On the other hand, because ILM practices may be complementary to delegation of decision-making as hypothesized in HC4, and delegation of decision-making and incentives are also expected to be complementary (HB1), transitivity suggests that ILM practices could also be complementary to incentives. Overall, there is no theoretically unambiguous prediction regarding the relationship between incentives and monitoring and delegation and between incentives and ILM practices; we refer to them as empirical questions to investigate in order to guide future theoretical developments in organization design.

In sum, appropriate exercise of decision-making is induced by incentives, monitoring and ILM; these practices may substitute for as well as complement each other. Figure 1 summarizes the main relationships between internal uncertainty and organization design. The complete set of hypotheses is also summarized there. In the next section we use three models (A, B and C) to test the theoretically predicted relationships, and to adduce evidence on the theoretically indeterminate relationships.

required effort level). The relative cost of monitoring may also be affected by uncertainty; Prendergast (2002b) shows that in presence of supervisor favoritism, greater uncertainty leads firms to rely more on incentives and less on monitoring.

${ }^{14}$ For a model of this argument in the context of academic tenure as an ILM, see Chen (2005). In a related fashion, Carmichael (1988) argues that tenure is needed to induce professors to provide specialized information that is not available to administrators. 


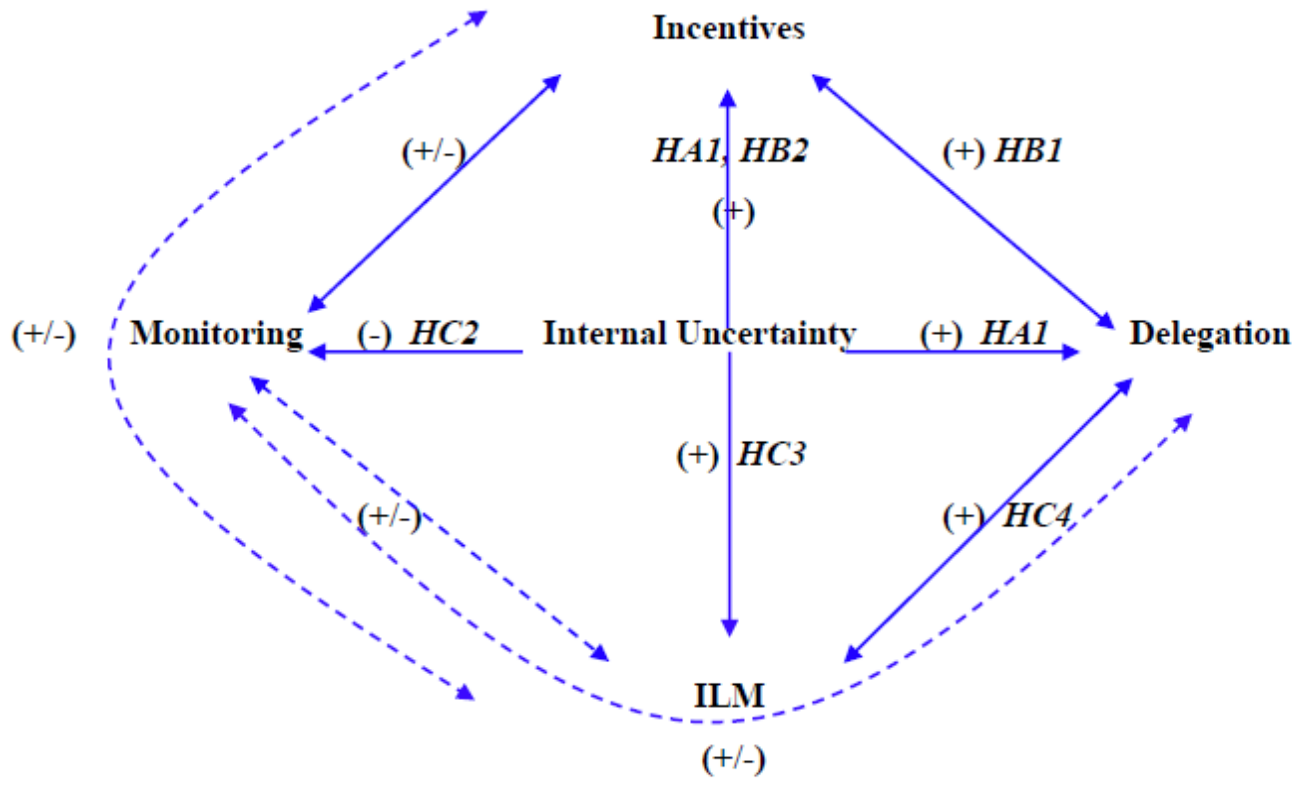

Notes: $\longrightarrow=$ theoretically unambiguous relationships. $-\rightarrow=$ theoretically ambiguous relationships.

\section{Summary of hypotheses}

\begin{tabular}{|l|l|l|}
\hline \multicolumn{1}{|c|}{ Model A } & \multicolumn{1}{|c|}{ Model B } & \multicolumn{1}{c|}{ Model C } \\
\hline $\begin{array}{l}\text { Hypothesis HA1: Internal } \\
\text { uncertainty associated with the task } \\
\text { environment is positively correlated } \\
\text { with the use of delegation of } \\
\text { decision-making and with incentives. }\end{array}$ & $\begin{array}{l}\text { Hypothesis HB1: Incentives and } \\
\text { delegation of decision-making are } \\
\text { positively correlated. }\end{array}$ & $\begin{array}{l}\text { Hypothesis HC1: The } \\
\text { correlation between } \\
\text { delegation of decision- } \\
\text { making and incentives } \\
\text { changes after the inclusion of } \\
\text { ILM practices and } \\
\text { monitoring to the equation } \\
\text { that explains incentives. }\end{array}$ \\
\hline $\begin{array}{l}\text { Hypothesis HA2: The correlation } \\
\text { between internal uncertainty and } \\
\text { incentives is positive and is stronger } \\
\text { at the individual level than at the } \\
\text { group and firm levels. }\end{array}$ & $\begin{array}{l}\text { Hypothesis HB2: The correlation } \\
\text { between internal uncertainty and } \\
\text { incentives decreases when } \\
\text { delegation of decision-making is } \\
\text { taken into account. }\end{array}$ & $\begin{array}{l}\text { Hypothesis HC2: Internal } \\
\text { uncertainty is negatively } \\
\text { correlated with the use of } \\
\text { monitoring. }\end{array}$ \\
\hline $\begin{array}{l}\text { Hypothesis HA3: The correlation } \\
\text { between external uncertainty and } \\
\text { incentives is negative and is stronger } \\
\text { at the firm level than at the individual } \\
\text { and group levels. }\end{array}$ & $\begin{array}{l}\text { Hypothesis HB3: The correlation } \\
\text { between external uncertainty and } \\
\text { incentives decreases when } \\
\text { delegation of decision-making is } \\
\text { taken into account. }\end{array}$ & $\begin{array}{l}\text { Hypothesis HC3: Internal } \\
\text { uncertainty is positively } \\
\text { associated with ILM } \\
\text { (training, promotion-from- } \\
\text { within and employment } \\
\text { security). }\end{array}$ \\
\hline & $\begin{array}{l}\text { Hypothesis HC4: Delegation } \\
\text { of decision-making and ILM } \\
\text { practices are positively } \\
\text { correlated. }\end{array}$ \\
\hline
\end{tabular}




\section{Data and Method of Analysis}

\subsection{Description of the Dataset}

The sample is drawn from the Minnesota Human Resources Management Practices Survey. The survey was administered from 1994 to 1996 to 2,021 private forprofit Minnesota-based firms with at least 20 employees, representing a broad spectrum of industries. In order to ensure representation of diverse industries, ownership forms, and firm sizes, a stratified sampling strategy was employed. The first stage included nearly 600 firms: all publicly-traded firms, and firms that were known to have employee stock ownership plans. The second stage included 1,500 firms: all retail food firms and a representative sample of 958 firms from all industries excluding agriculture. The overall response rate was $43 \%$ (874 surveys). Respondents were typically the highest human resources executive in the firm; in smaller firms the respondent was frequently the top executive in the firm.

The survey questionnaire asked about individual-, group-, and firm-level incentives, various human resource practices such as training, the degree of employee participation in decision making, the nature of the tasks carried out by shop-floor employees, and other aspects of firm organization. ${ }^{15}$ Many of the questions focused on shop-floor or core employees, the largest group of non-supervisory, non-managerial employees who are directly involved in making the product or providing the service, such as assembly-line workers at an auto manufacturing factory, computer programmers in a software company, or sales representatives in an insurance company (Osterman, 1994). Most of the variables employed in our analyses are derived from responses to the survey.

Additional variables were constructed from the COMPUSTAT dataset for publicly traded firms (industry-level external uncertainty and capital-labor ratio), and Minnesota Department of Economic Security (number of employees and wage bill in sample firms), which were merged with the survey data. The working sample, after deleting firms that did not meet inclusion criteria and firms with missing information,

\footnotetext{
${ }^{15}$ The survey is available at https://netfiles.umn.edu/users/benne001/www/papers/work-surv/work-surv01.pdf.
} 
consists of 640 firms. ${ }^{16}$ However, missing observations for control variables further reduce the size of the working sample to 530 firms.

\subsection{Variables}

Table A1 in Appendix A provides definitions, sources, and descriptive statistics of all variables. The uncertainty variables are constructed as follows. Internal uncertainty is the sum of the degree of complexity, variability and (reverse coding of) routine attributes of the tasks carried out by shop-floor workers, corresponding to our earlier theoretical discussion. The items, measured on a 5-point scale, ask directly about the extent to which core employees' tasks are complex, variable, and routine. Results based on task complexity alone as measure of internal uncertainty are very similar to those based on the broader measure, and are available upon request.

External uncertainty is measured by the standard deviation of the net income in the firm's 3-digit SIC industry over the period 1990-1994 (the five years preceding the survey). This is one of several measures of risk proposed in the literature; most of the measures are correlated because they tap into various aspects of variability in profitability over time. ${ }^{17}$ It is not a perfect exogenous noise measure affecting core employees' performance as described in our theoretical framework for two reasons. First, it is incomplete because it does not reflect uncertainty caused by equipment and actions of other units in the firm and second, in some firms and industries core employees may be able to gather information about the external environment and react to it (in most industries core employees' actions are not likely to be directly influenced by the uncertainty in the industry because they are generally shielded from it by several layers in the organization). Thus external market uncertainty as measured in our study is generally not a respondable risk for core employees. ${ }^{18}$

\footnotetext{
${ }^{16}$ Our inclusion criteria are: firms that at the time of the survey were headquartered and employed a majority of employees in Minnesota, operated in industries that carry a main four digit SIC code outside agriculture, were for-profit and employed at least 20 employees. Surveys with missing information on any of the organization design or task environment variables were not used.

${ }^{17}$ See, for example, Bromiley and Miller (1990) and Ruefli et al., (1999) for reviews. An empirical measure of external uncertainty that affects specifically the shop floor is unavailable. However, it is likely that noise originating in other organization units that interact with the shop floor is correlated with market noise.

${ }^{18}$ The same external uncertainty measure is a respondable risk for executives, who collect information about the market and act upon that information (Shi, 2010).
} 
The organization design variables concern incentives, delegation of decisionmaking, monitoring, and ILM practices. Wherever possible we distinguish between the individual, group and firm-level variables. We use dummy variables to identify the existence of individual incentive plans, group-level incentives (group bonus), and firmlevel incentives (cash and deferred profit sharing plans).

Delegation of decision-making to individual employees is described by two alternative variables, both measured on a 5-point scale: the degree of control these employees have over how their jobs are done and the degree of participation by core employees in employee involvement programs. ${ }^{19}$ Delegation of decision-making to groups is captured through a dummy indicating the use of self-managed teams.

Monitoring is represented by an item that asked about the degree to which core employees' work is monitored by supervisors on a 5-point scale. We also use a related measure based on an item that asked about the degree to which core employees' work is guided and directed by supervisors and managers. These items were added in the second stage of the survey administration; as a result, the sample for the analyses that include monitoring (Table 2) and guidance (Appendix B) consists of 305 firms rather than 530 (Table 1). Individual-level ILM practices include employment security, promotion from within and on-the-job training; group-level ILM is represented by team training.

\subsection{Empirical Strategy}

We estimate a series of incremental models, taking into consideration the discrete nature of the organization design variables. In Models A and B we estimate the determination of incentives and delegation of decision-making; in Model $\mathrm{C}$ we put forth a more comprehensive approach to the understanding of the relationships between uncertainty and organization design as well as among multiple elements of organization design.

\footnotetext{
${ }^{19}$ The two measures of individual delegation of decision-making are derived from responses to survey questions: "To what extent do these [core] employees: have control over how their work is done" (for the control variable), and "To what extent do these [core] employees: participate in any employee involvement programs" (for the involvement variable). Earlier in the questionnaire examples of employee involvement programs were given: suggestion system, quality of work life, quality circles, total quality management, self-managing work-team, joint labor-management committees, employee representative on the board of directors.
} 
In Model A, we analyze the role of internal uncertainty in the choice of delegation of decision-making and provision of incentives in a fashion similar to Foss and Laursen (2005) and DeVaro and Kurtulus (2010). A simultaneous equations model is appropriate in this case because both incentives and delegation are likely to be affected by common unobservable factors.

\section{Model A}

\section{(1) $\quad$ Prob(Incentives $)=g\left(X, I U, E U, e_{1}\right)$}

(2) $\quad \operatorname{Prob}($ Delegation $)=f\left(X, Z, I U, E U, e_{2}\right)$

where $I U$ is internal uncertainty, $E U$ is external uncertainty, $\boldsymbol{X}$ reflects firm characteristics (described and justified later) and $\left(\boldsymbol{e}_{1}, \boldsymbol{e}_{2}\right)$ is bivariate normal $\mathrm{N}(0, \Sigma) .{ }^{20}$ For identification of the model (beyond non-linearities), ${ }^{21} \mathbf{Z}$ includes a variable that affects the choice of delegation but not of incentives; the variable is an index of employee participation related to decision-making issues. The information comes from a survey question (on a scale of 1 to 5): "To what extent do employees participate in the following issues?" The responses are: work rules, working conditions, pay and other compensation, selection of personnel, training and development, social events, job redesign, safety and health, equipment maintenance, selection of materials, selection of new equipment, investment policies, production planning, profit allocation and corporate finance. We chose issues that involve some degree of decision-making: selection of personnel, job redesign, investment policies, production planning and profit allocation. We built an intensity index that sums the scores on each issue. The correlations between the index and individual, group and firm level incentives are low $(0.11,0.16$ and 0.26 , respectively). We experimented with the definition of the index including a larger set of the participation issues as well as using a different question ("To what extent does management share information with nonmanagerial employees in the following areas: investment policies, production planning

\footnotetext{
${ }^{20}$ The variance-covariance matrix $\Sigma$ is non-diagonal as we assume correlation in the disturbance terms across equations. $\Sigma=\left(\begin{array}{ll}1 & \rho \\ \rho & 1\end{array}\right)$

${ }^{21}$ Identification of the model can be obtained without exclusion restrictions and consideration of variable $\mathrm{Z}$. However, because the recursive property of Models B and C may require such exclusion restrictions (Maddala, 1983, p 122-123), we systematically defined instruments. We provide more details on this issue when we introduce Model C.
} 
and human resources planning") and report in the robustness checks section that we find no major differences in the results.

Prendergast's (2002a) main argument is incorporated in Model B, which is identical to Model A except that delegation is added in equation (1).

\section{Model B}

\section{(1) $\quad \operatorname{Prob}($ Incentives $)=g\left(X\right.$, Delegation, $\left.I U, E U, e_{1}\right)$ \\ (2) $\quad \operatorname{Prob}($ Delegation $)=f\left(X, Z, I U, E U, e_{2}\right)$}

Next we specify a more general model that incorporates delegation of decisionmaking, incentives, internal labor markets, and monitoring. We can think of effort as being produced by incentives, monitoring, and ILM as inputs, in the spirit of Demougin and Fluet's (2001) model. Since effort is unobservable, we use instead the firm's average wage, which in a competitive market is highly correlated with the firm's average effort. We estimate the relationships among incentives, monitoring and ILM practices, controlling for effort-wage; this is analogous to estimating the relationship between labor and capital along an isoquant by controlling for the level of output.

Following the empirical literature on the determinants of adoption of systems of workplace practices, the extent of substitution and complementarity between organizational practices is likely to vary by the type of industry and technology used by the firm. We therefore control for industry (at the 1 digit level) and the firm's capitallabor ratio. ${ }^{22}$ The estimated parameters reflect correlations among elements of organization design, with a negative coefficient on a particular practice suggesting substitutability between the practice and incentives, and a positive coefficient complementarity. Because correlations among organizational design practices may be affected by firm unobserved heterogeneity (Athey and Stern, 1998), and because the cross-sectional nature of our dataset does not permit treatment of firm-specific effects, we are not able to infer from the sign of an estimate more than an indication of substitution or complementarity. We control for observable firm heterogeneity by including the age

\footnotetext{
${ }^{22}$ Huselid and Rau (1997), using data on US firms across a wide range of industries from 1991 to 1995 , find that more capital intensive firms are more likely to adopt systems of practices that combine employee involvement, incentives and acquisition and deployment of employee skills (see Huselid 1995 for a definition of the various delegation, training and incentive practices).
} 
and the size of the firm in addition to the firm's average wage, industry and capital-labor ratio. Monitoring, training, promotion-from-within and commitment to employment security are also likely to be increasingly costly as the size of the firm increases. Furthermore, unions may influence the mix of practices, particularly those that involve incentives and employee skills development; we therefore control for firm unionization status. To summarize, $\boldsymbol{X}$ includes industry, industry-level capital-labor ratio, union status, number of employees (log), firm age (log) and average wage (log).

The model is formally described below.

\section{Model C}

(1) $\quad \operatorname{Prob}($ Delegation $)=g\left(X, Z, I U, E U, u_{4}\right)$

(2) $\quad \operatorname{Prob}(M o n i t o r i n g)=h\left(X, Q, I U\right.$, Delegation, $\left.E U, u_{3}\right)$

(3) $\quad \operatorname{Prob}(I L M)=j\left(\left(X, R, I U\right.\right.$, Delegation, Monitoring, EU, $\left.u_{2}\right)$

(4) $\quad$ Prob(Incentives) $=f\left(X, E U, I U\right.$, Delegation, Monitoring, ILM, $\left.u_{1}\right)$

where $\left(\boldsymbol{u}_{1}, \boldsymbol{u}_{2}, \boldsymbol{u}_{3}, \boldsymbol{u}_{4}\right)$ is quadrivariate normal $\mathrm{N}\left(0, \Sigma^{\prime}\right) .{ }^{23}$ We build the model in a hierarchical fashion, starting with estimation of delegation of decision-making (which we argued in the previous section is the key organization design choice), followed by equations determining the choice of monitoring and internal labor markets, and ending with the estimation of incentives.

To account for unobservable common influences on the choice of organization design variables as well as for the direct interdependence among these variables (which implies that dependent variables are on the right hand side in some equations), we use a recursive multivariate probit model to estimate a system of simultaneous equations. ${ }^{24}$ Note that each equation contains a common set of variables $\boldsymbol{X}$ which reflects firm characteristics. Because identification of the parameters in recursive multivariate probit models has been debated, ${ }^{25}$ we also consider additional equation-specific variables $\boldsymbol{Z}, \boldsymbol{Q}$,

\footnotetext{
${ }^{23}$ The matrix of variance-covariance $\Sigma^{\prime}$ is non-diagonal and assumes correlation $\rho_{\mathrm{ij}}$ in the disturbance terms across equations.

${ }^{24}$ The recursive bivariate probit model is discussed in Maddala (1983, p122-123). It has been applied, for example, by Eisenberg and Rowe (2009) to analyze the effect of serving in the Vietnam war on smoking. ${ }^{25}$ According to Maddala (1983), the parameters cannot be identified if the error terms of the equations are correlated and the right-hand side variables are identical across equations. He shows an example using the
} 
and $\boldsymbol{R}$. These variables are chosen so that they influence the use of delegation, monitoring and internal labor market practices, respectively, but do not directly affect the decision to provide incentives. For consistency and comparability across models, $\mathbf{Z}$ is defined as in Models A and B. For $\boldsymbol{Q}$, we use the number of employees per supervisor and for $\boldsymbol{R}$ we use a variable on the extent (on a scale of 1 to 5) of employee participation in decisions regarding personnel training and development.

We use the method of simulated maximum likelihood (SML) provided in the mvprobit procedure in Stata. ${ }^{26}$ Although this approach does not permit identification of causal effects, it helps understand the relationship between uncertainty and organization design, and among elements of organization design.

The use of probit estimations involves defining the categorical organization design variables, monitoring and delegation, as binary, high and low. We define high levels as values of the variables greater than 3 . Because collapsing these variables implies losing some variation in the data, we also estimated the models using three-stage least squares in order to take advantage of the whole range of values for the monitoring and delegation variables.

\section{Results}

\section{Models $A$ and $B$}

The results for Models A and B are presented separately for individual-level incentives in Tables $1 \mathrm{a}$ and $1 \mathrm{~b}$ (using alternative delegation measures, employee participation in involvement programs and employees' control over their jobs), grouplevel incentives in Table 1c and firm-level incentives in Tables 1d and 1e (using alternatively cash profit sharing and deferred profit sharing). Results from simultaneous estimations of equations (1) and (2) of Model A are presented in the left panel. Results for Model B, which adds delegation in the determination of incentives, are in the right panel.

model with only constant terms and no $\boldsymbol{X}$ variables. Wilde (2000) shows that no exclusion restrictions are needed if there is sufficient variation in $\boldsymbol{X}$ variables in the data.

${ }^{26}$ This routine estimates off-diagonal correlations for the variance-covariance matrix using the GewekeHajivassiliou-Keane (GHK) simulator to evaluate each of the normally distributed integrals in the likelihood function. See Cappellari \& Jenkins (2003) for more details on the mvprobit procedure. 
For Model A, internal uncertainty is associated with a higher likelihood of delegation of decision-making at all levels of incentives (first column in Tables 1a-1e). The marginal effects imply that an increase of one standard deviation in internal uncertainty (2.14) increases the probability that the firm will use individual delegation as involvement by $0.089(2.14 * 0.042)$, individual delegation as control by $0.124(2.14 * 0.06)$ and team delegation by $0.083(2.14 * 0.039)$. These effects are statistically highly significant and their magnitude is reasonable, suggesting that the estimated relationships are economically meaningful. We conclude that hypothesis $\mathbf{H A 1}$ is supported.

Consistent with HA2, the marginal effects reflecting the association between internal uncertainty and incentives is positive and is stronger for individual incentives than for group bonus and profit sharing. The association between external uncertainty and incentives is strongest for profit sharing suggesting that the impact of uncertainty on incentives depends also on the level at which uncertainty and incentives are measured.

We find support for HA3: external uncertainty is not statistically significantly associated with incentives at the individual or group level but at the firm level it is strongly negatively correlated with the use of deferred profit sharing (Table 1e). The marginal effect estimated suggests that a one standard deviation increase in external uncertainty reduces the likelihood of using deferred profit sharing by $0.073(1.79 *-0.041)$.

For Model B, the positive association between internal uncertainty and delegation is still present and of similar magnitude as in Model A. Consistent with HB1, in all specifications delegation is strongly positively associated with the use of incentives, suggesting complementarity between the two practices at the individual, group and firm levels. The marginal effects suggest that the use of delegation is associated with an increase in probability of using incentives between 0.27 and 0.51 .

Consistent with hypothesis $\mathbf{H B 2}$, the relationship between internal uncertainty and incentives in Model B is weaker than in Model A for all levels of incentives: taking delegation into account clearly reduces the effect of internal uncertainty on incentives.

These results are consistent with Prendergast (2002a). These predictions were also empirically confirmed by Foss and Laursen (2005) using a cross-section of Danish firms in 1996 and DeVaro and Kurtulus (2010) using a sample of British establishments in 1998. The similarity in their findings to ours using U.S. firms during the same period 
suggests that the predictions on the risk-incentives relationship are robust across countries for the period of the middle to late 1990s. Interestingly as well, the magnitude of the association between delegation and incentives (individual performance pay plans) is similar to the one found in DeVaro and Kurtulus (2010): estimated coefficient of 0.947 in Table 5 compared to our estimate of 0.957 when we used individual incentives and delegation as involvement and 1.25 when we use delegation as control. This suggests that whether delegation reflects involvement, control or authority (as stated in the British dataset used by DeVaro and Kurtulus), the association between delegation and incentives is robust to different datasets and between the U.S. and England.

Regarding the possibility of endogeneity in the models, we do not find evidence of a significant correlation between delegation of decision-making in firms' decisions and incentives in Model A. The estimated correlation between the residuals of the delegation and incentives equation $(\rho)$ in Model $\mathrm{A}$ is never statistically significant for individual, group and firm-level incentives. On the other hand, there is evidence of a negative correlation in the residual errors after delegation has been included in the model (Model B). This implies that unobservable factors in the error terms are correlated even after taking into account the complementarity between incentives and delegation. This result provides additional motivation for investigating the relationship between uncertainty and a more complete set of organization design practices. In other words, adding other organization design practices to the decision to use incentives is likely to affect the association between delegation and incentives found in Model B as it might be suffering from an omitted variable bias as hypothesized in $\mathbf{H C 1}$.

\section{$\underline{\text { Model C }}$}

Results for the three levels of incentives for Model C are presented in Tables 2a$2 \mathrm{~b}, 2 \mathrm{c}$, and $2 \mathrm{~d}-2 \mathrm{e}$. Individual-level incentives are paired with individual delegation of decision-making, whereas both group-level and firm-level incentives are paired with team delegation of decision-making. ${ }^{27}$ For Model C we use three measures for ILM: onthe-job training matched with individual incentives and team training for group- and firm-level incentives; we also use employment security and promotions as additional

\footnotetext{
${ }^{27}$ Theoretically, firm-level incentives should be matched with firm-level delegation of decision-making to employees (Ben-Ner and Jones, 1995), but this is not observed in our data, with the exception of a handful of firms that have employee representation on the board.
} 
ILM measures for all three levels of incentives. Additional robustness checks, including an alternative specification of monitoring and an alternative estimation approach and model specification, are presented later in this section.

Tables 2a-2e present Model $\mathrm{C}$, with recursive simultaneous equations estimation of delegation, monitoring, ILM practices and incentives, using multivariate probit. The results concerning internal uncertainty, delegation and incentives are consistent with the results found in the simpler Model B: internal uncertainty is statistically significantly associated with a greater likelihood of using delegation of decision-making and has a weak to insignificant association with the likelihood of using incentives across all levels. This result suggests that the main prediction in Prendergast (2002a) holds when additional organizational design practices are taken into account. Consistent with HC1, in all incentives equations the positive association between delegation and incentives is weaker than in Model B suggesting the correlation estimated in the previous literature suffered from an upward bias. This result is evidence for the importance of monitoring and ILM practices in firms' decisions to combine delegation and incentives. We will further discuss the bias when we describe the empirical correlations between ILM practices (and monitoring) and delegation and incentives.

Regarding hypothesis $\mathbf{H C}$, we find a statistically significant negative correlation between internal uncertainty and monitoring across all levels of incentives. (The results in Appendix B, which use guidance instead of monitoring, are similar). The estimates are of similar magnitude to those found on the likelihood of delegation of decision-making, but of opposite sign, across the different levels. This finding is consistent with the idea that uncertainty increases the cost of monitoring relative to delegation. We find no statistically significant relationship between external uncertainty and monitoring.

The use of ILM practices is positively associated with internal uncertainty, but only in few specifications is the association statistically significant, providing only partial support for HC3. Whenever the correlation is statistically significant, it concerns the increased effect of internal uncertainty on the likelihood of using promotion and training practices. External uncertainty has a weak negative association with the likelihood of promotions although it is statistically significant at the group and firm levels, suggesting 
that managers are more cautious in using promotions when external uncertainty can affect group and firm performance.

We find mild support for HC4: the correlation between delegation and ILM practices is positive but statistically insignificant in nearly all specifications, and is positive and significant between team delegation and training and promotions when associated with the use of group bonus. ${ }^{28}$

We turn now to an analysis of relationships for which we did not formulate unambiguous predictions and seek empirical information to help identify more precisely tradeoffs between various effects of different organization design elements. Consider first the relationship among ILM practices, monitoring and incentives. The relationship between monitoring and incentives in the equation where ILM practices are included is positive $^{29}$ and is statistically significant with individual incentives in several specifications of ILM. On the other hand, employment security reduces the likelihood of using individual incentives while promotions and training both increase the likelihood of using individual, group and firm level incentives. There is also a significantly positive correlation between employment security and monitoring at the individual level. These last two results suggest that firms seem to be more likely to use a combination of delegation of decision-making and individual incentive pay and less likely to use monitoring and employment security practices. Given the impact of uncertainty on delegation and monitoring described earlier, these associations are likely to be stronger in presence of greater internal uncertainty. Returning to the interpretation of an upward bias in the relationship between incentives and delegation associated with the omission of monitoring and ILM practices, the positive bias seems to be driven by the statistically significant positive correlations between monitoring and incentives and between ILM practices (promotion and training) and incentives. For employment security, the statistically significant correlation between employment security and incentives is negative (for individual incentives) while no negative correlation between employment security and delegation seems to be present to create a positive bias. However, the bias is

\footnotetext{
${ }^{28}$ The correlation between delegation-involvement and these two ILM practices is negative but insignificant in the presence of individual incentives. This is the only instance of negative correlation between delegation and ILM practices in our specifications.

${ }^{29}$ There is one single statistically insignificant exception, with cash profit sharing in the presence of ILMpromotions.
} 
also a function of the correlations between employment security and the other variables included in the incentives equation. In particular, we note the potential offsetting effect of the strong positive correlation between monitoring and employment security. ${ }^{30}$

Regarding the correlations in the residuals of each equation $\left(\rho_{\mathrm{ij}}\right)$, the joint test of significance cannot reject the null of joint equality of the estimated correlations for the individual and group-based incentive plans when either promotions or training is used. This result suggests that for individual and group-based incentives, Model $\mathrm{C}$ offers a more complete account of the correlations between the organizational design practices and their relationship with uncertainty compared to Model B, for which there was evidence of endogeneity and unobserved factors creating correlations in the residuals.

For estimations with employment security, the estimated residual correlations are largest with monitoring at all three levels; the correlations are all negative. This suggests that unobservable factors may influence the joint choice of monitoring and employment security. We also find that for cash profit sharing plans there are strong negative correlations with delegation for all three ILM measures. This suggests that the riskincentive relationship for profit sharing plans might involve more (or other types of) decisions than delegation of decision-making, monitoring and ILM practices.

To summarize the results, we find evidence that in our more general setting the effect of internal and external uncertainty on incentives is weakened when taking into account not only delegation but also monitoring and ILM practices. Internal uncertainty consistently reduces the likelihood of using monitoring and in most specifications it increases the likelihood of using promotions and training. Based on the correlations between the various practices across the different levels of incentives, the results suggest complementarity between incentives and delegation and between incentives and promotions and training, at the individual, group and firm levels. Incentives and employment security are possible substitutes. Firms are more likely to use a combination of delegation of decision-making and individual incentive pay and less likely to use

\footnotetext{
${ }^{30}$ Obtaining a precise formula for the bias is difficult. In the single omitted variable case the bias is based on the product of the correlation between previously omitted ILM practices (for example) and delegation, and the correlation between the omitted ILM practice and incentives. In the general case with multiple regressors, the omitted variable is also correlated with the other variables in the incentives equation (for example internal uncertainty and monitoring) creating additional pairwise correlations susceptible to influence the bias.
} 
monitoring and employment security practices. Firms also seem to be more likely to use incentive pay with promotions and training practices and (in the case of training) to combine it with monitoring.

\subsection{Robustness checks}

We reestimated the models in Tables 1 and 2 using 2SLS and 3SLS estimations, exploiting the categorical nature of the delegation and monitoring variables. Because the two sets of estimates are very similar and the 3SLS are more efficient, we report only the results from the 3SLS estimations. The results, presented in Appendix C, are qualitatively similar to the bivariate and multivariate probit estimations presented in Tables 1 and $2 .^{31}$

We reran the estimations in Tables 1 and 2 with different variables for $\boldsymbol{Z}$. For example, we used answers to the question: "To what extent does management share information with non-managerial employees in the following areas: investment policies, production planning and human resources planning?" Whether we used an index representing the sum of the scores on several responses or only a dummy indicating one of the answers, the main results remained qualitatively similar: the effects of internal and external uncertainty on incentives drop substantially once delegation, monitoring and ILM practices are taken into account in the decision to use incentive plans, with the strongest effect for individual and group incentive plans.

We also reran the estimations in Table 2 replacing the variable related to monitoring with a variable related to the extent to which workers have their work guided and directed by supervisors and managers, a practice similar to monitoring. The results, presented in Appendix B, are very similar to those in Table 2, confirming the robustness of the results to alternative measures of monitoring.

To test the robustness of the results associated with the reduced sample size when monitoring is introduced in Model $\mathrm{C}$, we reran the analyses underlying Table 1 using the reduced sample of Table 2 . The results were very similar, suggesting that the two samples, those who received the survey in the first stage and those who received it in the second stage with the added monitoring and guidance questions, exhibit the same patterns.

\footnotetext{
${ }^{31}$ The standard errors differ, changing significance levels. Because heteroscedasticity affects linear probability models, we do not place much weight on the difference in statistical significance.
} 
Finally, we replicated the analysis for model $\mathrm{C}$, reversing the specifications for ILM and monitoring and found the results to be very similar.

\section{Discussion and Conclusions}

Organization design may be viewed as a set of responses to informational issues aimed at ameliorating agency and technical problems that cause or allow employees to apply lower and less apt effort than it is in the interest of the firm. The informational issues faced by employees and their supervisors arise from the nature of the task environment as well as from the external environment. Firms respond by way of delegating decision-making from supervisors to better-informed employees and by motivating employees with incentives, monitoring them, training them, offering promotions and the inducement of employment security, and more. Expanding on the organizational economics literature, we developed a framework for (a) the examination of the relationship between uncertainty (internal and external) and various elements of organization design, and (b) the analysis of the relationships among elements of organization design.

From the theoretical framework we developed several hypotheses and availing ourselves to a uniquely rich dataset of a cross-section of firms in Minnesota, we tested them empirically. We found that the degree to which the task environment of core employees is complicated has an important role in explaining organization design at the shop-floor level. The degree of volatility in the firm's product market bears only a weak relationship to organization design at the shop-floor level. The design of the shop floor is largely insulated from the external risk but is quite responsive to the internal uncertainty associated with the immediate task environment. Prendergast (2002a) has it right: internal uncertainty that arises from the unobservable influence that employees have over outcomes calls for delegation of decision-making to them. In order to induce better effort from employees, they are offered various incentives - hence a positive relationship between internal uncertainty and incentives will be observed empirically, but if delegation of decision-making is included in the estimation, the positive relationship weakens to the point of statistical insignificance. This is precisely what we found, validating findings by Foss and Laursen (2005) in Danish and DeVaro and Kurtulus 
(2010) in British data, attesting to the robustness of the risk-incentives relationship across different countries and datasets. Our paper also showed that this relationship exists in our data at the individual, group and firm levels.

In an expanded model of organization design, including monitoring and different practices associated with internal labor markets, we found that internal uncertainty continues to be positively associated with delegation of decision-making, and is negatively associated with monitoring (presumably because the more complicated the task environment, the more expensive it is to monitor employees). However, individual and group-level incentives are not linked to internal uncertainty, nor are internal labor market practices.

External uncertainty as measured by market volatility is only weakly associated with organization design elements: it has a weak positive relationship with delegation (presumably in firms where core employees interact directly with the market), and has a weak negative relationship with deferred profit sharing (probably because management does not want to impose much risk on employees, the classic risk-incentives tradeoff).

We also examined the substitution and complementarity relationships among the various elements of organization design relative to uncertainty. The robust and positive association between delegation of decision-making and incentives is present at all three organizational levels. Delegation and incentives are also positively associated with the use of promotions and training. We find no significant correlations between monitoring and delegation or monitoring and incentives. However, monitoring is positively correlated with employment security. In view of our conceptual framework, this provides support for the hypothesis that decision-making plays a central role in organization design, with other elements playing a support or accommodating role.

From a firm policy standpoint, these results imply that organization design for core employees takes shape mainly in response to the characteristics of the firm's production technology and business strategy. Thus, in choosing and improving workplace organization, managers do not need to systematically react to the product market but need to operate on the basis of long-term objectives. Furthermore, our findings, like those of Ichniowski and Shaw (2003), Ennen and Richter (2010) and others, imply that managers must regard the act of organization design as a deliberate and careful puzzle-like 
assemblage of practices that complement and substitute each other rather than the collection of best practices identified for their individual merits.

In conclusion, we find that the task environment, as the source of internal uncertainty, influences strongly organization design by affecting the desired allocation of decision-making; additional practices are employed to support appropriate exercise of decision-making by employees. Firms choose the specific elements of design in view of complementarity and substitution relationships among them; unobserved heterogeneity among firms in our cross-sectional dataset, a limitation of our study, does not permit us to deduce strict complementarity and substitution from the signs of the estimates on organization design elements.

Another limitation of our study is that we do not have information about the cost of employing various elements of organization design, which is certain to affect the relative reliance on them. Data on the cost of most organizational practices are not available in administrative datasets and are nearly impossible to obtain through surveys. Inferences on costs on the basis of the complexity of the task environment are insufficient. Laboratory and field experiments designed to capture key aspects of these costs such as those designed by Nagin et al. (2002) and Dickinson and Villeval (2008) represent a fruitful area of research in organization design.

\section{References}

Aoki, M., 1988. Information, incentives, and bargaining in the Japanese economy. Cambridge University Press, New York/Cambridge.

Athey, S., Stern, S., 1998. An empirical framework for testing theories about complementarity in organizational design. NBER, Working Paper.

Autor, D., Levy, F., Murnane, R., 2003. The skill content of recent technological change: an empirical exploration. Quarterly Journal of Economics 118, 1279-1333.

Baker, G., Jorgensen, B., 2003. Volatility, noise, and incentives. Harvard Business School, Working Paper.

Baron, J. N., Kreps, D. M., 2000. Strategic human resources: frameworks for general managers. New York: John Wiley \& Sons. 
Ben-Ner, A., Jones, D., 1995. Employee participation, ownership, and productivity: a theoretical framework. Industrial Relations 34, 532-554.

Ben-Ner, A., Lluis, S., 2011. Learning: what and how? an empirical study of adjustments in workplace organization structure", Industrial Relations, 50(1), 76-108.

Ben-Ner, A., Montias, J. M., Neuberger, E., 1993. Basic issues in organizations: a comparative perspective. Journal of Comparative Economics 17, 207-242.

Bromiley, P., Miller, K. D., 1990. Strategic risk and corporate performance: an analysis of alternative risk measures. Academy of Management Journal 33, 756-779.

Cappellari, L., Jenkins, S. P., 2003. Multivariate probit regression using simulated maximum likelihood. Stata Journal 3, 221-235.

Cappelli, P., Neumark, D., 2001. Do 'high performance' work practices improve establishment-level outcomes? Industrial and Labor Relations Review 54, 737-775.

Carmichael, H. L, 1988. Incentives in academics: Why is there tenure? Journal of Political Economy, 96, 453-472.

Chen, Z., 2005. Incentive in academics: asymmetric information and tenure. Fudan University, Working Paper.

Delaney, J. T., Huselid, M. A., 1996. The impact of human resource management practices on perceptions of organizational performance. The Academy of Management Journal 39, 949-969.

Demougin, D., Fluet, C., 2001. Monitoring versus incentives. European Economic Review 45, 1741-1764.

DeVaro, J., Kurtulus, F. A., 2010,. An empirical analysis of risk, incentives, and the delegation of worker authority. Industrial and Labor Relations Review 63, 641-661.

Dickinson, D., Villeval, M., 2008. Does monitoring decrease work effort?: the complementarity between agency and crowding-out theories. Games and Economic Behavior 63, 56-76.

Eisenberg, D., Rowe, B.,. 2009. The effect of smoking in young adulthood on smoking later in life: evidence based on the Vietnam era draft lottery. Forum for Health Economics and Policy 12(2), Article 4.

Ennen, E., Richter, A., 2010. The whole is more than the sum of its parts: or is it? a review of the empirical literature on complementarities in organization. Journal of Management, 36(1), 207-233. 
Foss, N., Laursen, K., 2005. Performance pay, delegation, and multitasking under uncertainty and innovativeness: an empirical investigation. Journal of Economic Behavior and Organization 58, 246-276.

Garicano, L., 2000. Hierarchies and the organization of knowledge in production. Journal of Political Economy 108, 874-904.

Grandori, A., 1991. Negotiating efficient organization forms. Journal of Economic Behavior and Organization 16, 319-340.

Grossman S, Hart, O., 1986. The cost and benefit of ownership: A theory of lateral and vertical integration. Journal of Political Economy 94, 691-719.

Hart, O., Moore, J., 1990. Property rights and the nature of the firm. Journal of Political Economy 98, 1119-1158.

Hart, O., Moore, J., 2005. On the design of hierarchies: coordination versus specialization. Journal of Political Economy 113, 675-702.

Holmstrom, B., Milgrom, R. 1994. The firm as an incentive system. American Economic Review 84:4, 972-991.

Huselid, M., 1995. The impact of human resource management practices on turnover, productivity, and corporate financial performance. The Academy of Management Journal $38,3,635-672$.

Huselid, M.A. and Rau, B.L., 1997. The determinants of high performance work systems: cross-sectional and longitudinal analyses. Working Paper, Academy of Management Annual Meetings, Human Resource Management. Rutgers University. New Brunswick, NJ.

Ichniowski, C., Shaw, K., 2003. Beyond incentive pay: insiders' estimates of the value of complementary human resources practices. Journal of Economic Perspectives 17, 150180.

Ichniowski, C., Shaw, K., Prennushi, G., 1997. The Effects of human resource management practices on productivity: a study of steel finishing lines. American Economic Review 87(3), 291-313.

Ichniowski, C., Kochan, T., Levine, D., Olson,C., Strauss, G, 1996. What Works at Work, Industrial Relations 35(3), 299-333.

Lafontaine, F., Slade, M., 2001. Incentive contracting and the franchise design. In: Chatterjee, K., Samuelson, W. (Eds). Game Theory and Business Applications, Boston: Kluwer, 133-188. 
Laursen, K., Foss, N., 2003. New human resource management practices, complementarities, and the impact on innovation performance. Cambridge Journal of Economics 27, 243-263.

Lindbeck, A., Snower, D. J., 2000. Multitask learning and the reorganization of work: from tayloristic to holistic organization. Journal of Labor Economics 18, 353-376.

MacLeod, B. W., Carmichael, L., 2000. Worker cooperation and the ratchet effect. Journal of Labor Economics 18, 1-19.

MacLeod, B. W., Parent, D., 1999. Job characteristics and the form of compensation. Research in Labor Economics 18, 177-242.

Maddala, G. S., 1983. Limited Dependent and Qualitative Variables in Econometrics. New York: Cambridge University Press.

Manning, A., 2005. Technological change and demand for low-skill workers. Scottish Journal of Political Economy 51, 581-608.

March, J., Simon, H., 1993. Organizations, 2nd ed. Oxford: Blackwell.

Marschak, J., Radner, R., 1972. Economic Theory of Teams. New Haven: Yale University Press.

Milgrom, P., Roberts, J., 1992. Economics, Organization, \& Management. New Jersey: Prentice Hall.

Milgrom, P., Roberts, J., 1995. Complementarities and fit: strategy, structure, and organizational change in manufacturing. Journal of Accounting and Economics 19, 179208.

Miller, D., 1986. "Configurations of Strategy and Structure: Towards a Synthesis", Strategic Management Journal, vol 7, 233-249.

Nagar, V., 2002. Delegation and incentive compensation. The Accounting Review, 77, 379-395.

Nagin, D., Rebitzer, J., Sanders, S., Taylor, L., 2002. Monitoring, motivation, and management: the determinants of opportunistic behavior in a field experiment. American Economic Review 92, 850-873.

Neal, D., 1993. Supervision and wages across industries. The Review of Economics and Statistics 75, 409-417.

Osterman, P., 1994. How common is workplace transformation and who adopts it? Industrial and Labor Relations Review 47, 173-188. 
Osterman, P., 2000. Work Reorganization in an Era of Restructuring: Trends in Diffusion and Effects on Employee Welfare, Industrial and Labor Relations Review 53(2), 176-196.

Perrow, C., 1986. Complex organizations: a critical essay,3rd ed. New York: Random House.

Prendergast, C., 1999. The provision of incentives in firms. Journal of Economic Literature 37, 7-63.

Prendergast, C., 2002a. The tenuous trade-off between risk and incentives. Journal of Political Economy 101, 1071-1102.

Prendergast, C., 2002b. Uncertainty and incentives. Journal of Labor Economics 2, 115137.

Putterman, L., Kroszner R. S., 1996. The economic nature of the firm: a reader. New York: Cambridge University Press.

Raith, M., 2008. Specific knowledge and performance measurement. RAND Journal of Economics 39(4), 1059-1079.

Rantakari, H. V., 2008. On the role of uncertainty in the risk-incentives tradeoff. The B.E. Journal of Theoretical Economics 8(1), 1-23.

Rebitzer, J. B., 1995. Is there a trade-off between supervision and wages? An empirical test of efficiency wage theory. Journal of Economic Behavior and Organization 28, 107129.

Ruefli, T., James, C., Lacugna, J., 1999. Risk measures in strategic management research: auld lang syne? Strategic Management 20, 167-194.

Shi, L., 2011. Respondable risk and incentives for CEOs: The role of informationcollection and decision-making. Journal of Corporate Finance 17(1), 189-205.

Tyson, L., Levine, D., 1990. Participation, productivity, and the firm's environment. In: Blinder, A. (Ed.). Paying for Productivity, Washington, D.C.: Brookings Institution, 183237.

Wilde, J., 2000. Identication of multiple probit models with endogenous dummy regressors. Economics Letters, 69, 309-312.

Wulf, J. 2007., Authority, risk, and performance incentives: evidence from division manager positions inside firms. Journal of Industrial Economics 55, 169-196.

Zabojnik, J., 1996. Pay-performance sensitivity and production uncertainty. Economic Letters 53, 291-296. 
Zoghi, C., Levenson, A., Gibbs, M., 2005. Why are jobs designed the way they are? IZA, Discussion Paper. 
Table 1. Models A and B - Bivariate Probit

\begin{tabular}{|c|c|c|c|c|c|c|c|c|}
\hline & \multicolumn{4}{|c|}{ Model A } & \multicolumn{4}{|c|}{ Model B } \\
\hline & \multicolumn{2}{|c|}{$\begin{array}{l}\text { Individual } \\
\text { Delegation }\end{array}$} & \multicolumn{2}{|c|}{ Individual Incentives } & \multicolumn{2}{|c|}{$\begin{array}{l}\text { Individual } \\
\text { Delegation }\end{array}$} & \multicolumn{2}{|c|}{ Individual Incentives } \\
\hline & Coeff. & M. E. & Coeff. & M. E. & Coeff. & M. E. & Coeff. & M. E. \\
\hline Individual Delegation & & & & & & & $\begin{array}{c}0.957 * * * \\
(0.337)\end{array}$ & $\begin{array}{l}0.354 * * * \\
(0.124)\end{array}$ \\
\hline Internal Uncertainty & $\begin{array}{c}0.122 * * * \\
(0.030)\end{array}$ & $\begin{array}{l}0.042 * * * \\
(0.010)\end{array}$ & $\begin{array}{l}0.075 * * \\
(0.030)\end{array}$ & $\begin{array}{l}0.027 * * * \\
(0.010)\end{array}$ & $\begin{array}{c}0.121 * * * \\
(0.030)\end{array}$ & $\begin{array}{l}0.042 * * * \\
(0.011)\end{array}$ & $\begin{array}{c}0.027 \\
(0.035)\end{array}$ & $\begin{array}{l}0.009 \\
(0.012)\end{array}$ \\
\hline & $\begin{array}{l}-0.051 \\
(0.040)\end{array}$ & $\begin{array}{l}-0.017 \\
(0.013)\end{array}$ & $\begin{array}{c}0.008 \\
(0.041)\end{array}$ & $\begin{array}{l}0.003 \\
(0.014)\end{array}$ & $\begin{array}{l}-0.054 \\
(0.040)\end{array}$ & $\begin{array}{l}-0.018 \\
(0.014)\end{array}$ & $\begin{array}{c}0.026 \\
(0.042)\end{array}$ & $\begin{array}{l}0.009 \\
(0.015)\end{array}$ \\
\hline $\begin{array}{l}\log (\text { pseudo-likelihood }) \\
\rho\end{array}$ & & $\begin{array}{r}-6 \\
0 \\
0\end{array}$ & $\begin{array}{l}5.65 \\
164 \\
077) \\
\end{array}$ & & & $\begin{array}{r}-6 \\
-0 \\
0\end{array}$ & $\begin{array}{l}.82 \\
09^{*} \\
11) \\
\end{array}$ & \\
\hline
\end{tabular}

Table 1a: Individual Delegation (Involvement) and Individual-Level Incentives

Table 1b: Individual Delegation (Control) and Individual-Level Incentives

\begin{tabular}{|c|c|c|c|c|c|c|c|c|}
\hline \multirow{4}{*}{$\begin{array}{l}\text { Individual Delegation } \\
\text { Internal Uncertainty }\end{array}$} & \multicolumn{4}{|c|}{ Model A } & \multicolumn{4}{|c|}{ Model B } \\
\hline & \multicolumn{2}{|c|}{$\begin{array}{l}\text { Individual } \\
\text { Delegation }\end{array}$} & \multicolumn{2}{|c|}{ Individual Incentives } & \multicolumn{2}{|c|}{$\begin{array}{l}\text { Individual } \\
\text { Delegation }\end{array}$} & \multicolumn{2}{|c|}{ Individual Incentives } \\
\hline & Coeff. & M. E. & Coeff. & M. E. & Coeff. & M. E. & $\begin{array}{l}\text { Coeff. } \\
1.259 * * * \\
(0.271)\end{array}$ & $\begin{array}{l}\text { M. E. } \\
0.444 * * * \\
(0.093)\end{array}$ \\
\hline & $\begin{array}{l}0.151 * * * \\
(0.029)\end{array}$ & $\begin{array}{l}0.060 * * * \\
(0.011)\end{array}$ & $\begin{array}{l}0.074 * * * \\
(0.030)\end{array}$ & $\begin{array}{l}0.027 * * * \\
(0.013)\end{array}$ & $\begin{array}{l}0.148 * * * \\
(0.027)\end{array}$ & $\begin{array}{l}0.059 * * * \\
(0.011)\end{array}$ & $\begin{array}{l}-0.015 \\
(0.037)\end{array}$ & $\begin{array}{l}-0.006 \\
(0.014)\end{array}$ \\
\hline External Uncertainty & $\begin{array}{l}0.092 * * * \\
(0.037)\end{array}$ & $\begin{array}{l}0.037 * * * \\
(0.015)\end{array}$ & $\begin{array}{l}0.009 \\
(0.041)\end{array}$ & $\begin{array}{l}0.003 \\
(0.014)\end{array}$ & $\begin{array}{l}0.085^{* * *} \\
(0.037)\end{array}$ & $\begin{array}{l}0.033^{* *} \\
(0.015)\end{array}$ & $\begin{array}{l}-0.028 \\
(0.038)\end{array}$ & $\begin{array}{l}-0.010 \\
(0.014)\end{array}$ \\
\hline $\begin{array}{l}\log (\text { pseudo-likelihood }) \\
\rho\end{array}$ & & & $\begin{array}{l}6.01 \\
055 \\
976)\end{array}$ & & & & $\begin{array}{l}36 \\
2 * * \\
83)\end{array}$ & \\
\hline
\end{tabular}

\begin{tabular}{|c|c|c|c|c|c|c|c|c|}
\hline & \multicolumn{4}{|c|}{ Model A } & \multicolumn{4}{|c|}{ Model B } \\
\hline \multirow[b]{2}{*}{ Team Delegation } & \multicolumn{2}{|c|}{$\begin{array}{c}\text { Team } \\
\text { Delegation }\end{array}$} & \multicolumn{2}{|c|}{ Group Bonus } & \multicolumn{2}{|c|}{$\begin{array}{c}\text { Team } \\
\text { Delegation }\end{array}$} & Group Bonus & \multirow{4}{*}{$\begin{array}{c}\text { M. E. } \\
0.404^{* * *} \\
(0.126) \\
-0.001 \\
(0.010) \\
-0.002 \\
(0.012)\end{array}$} \\
\hline & Coeff. & M. E. & Coeff. & M. E. & Coeff. & M. E. & $\begin{array}{l}\text { Coeff. } \\
1.197 * * * \\
(0.337)\end{array}$ & \\
\hline Internal Uncertainty & $\begin{array}{l}0.143 * * * \\
(0.031)\end{array}$ & $\begin{array}{l}0.039 * * * \\
(0.009)\end{array}$ & $\begin{array}{c}0.054 * \\
(0.033)\end{array}$ & $\begin{array}{l}0.015^{*} \\
(0.009)\end{array}$ & $\begin{array}{l}0.153 * * * \\
(0.034)\end{array}$ & $\begin{array}{l}0.043 * * * \\
(0.009)\end{array}$ & $\begin{array}{l}-0.007 \\
(0.034)\end{array}$ & \\
\hline & $\begin{array}{l}-0.031 \\
(0.041)\end{array}$ & $\begin{array}{l}-0.009 \\
(0.012)\end{array}$ & $\begin{array}{l}-0.017 \\
(0.043)\end{array}$ & $\begin{array}{l}-0.004 \\
(0.012)\end{array}$ & $\begin{array}{l}-0.025 \\
(0.041)\end{array}$ & $\begin{array}{l}-0.007 \\
(0.011)\end{array}$ & $\begin{array}{l}-0.009 \\
(0.042)\end{array}$ & \\
\hline $\begin{array}{l}\text { Log(pseudo-likelihood) } \\
\rho\end{array}$ & & $\begin{array}{c}-53 \\
0.1 \\
(0.0\end{array}$ & $\begin{array}{l}6.66 \\
131 \\
785)\end{array}$ & & & & $\begin{array}{l}3.01 \\
11 * * \\
197)\end{array}$ & \\
\hline
\end{tabular}

Table 1c: Team Delegation and Group-Level Incentives (Group Bonus) 


\begin{tabular}{|c|c|c|c|c|c|c|c|c|}
\hline \multirow[b]{3}{*}{ Team Delegation } & \multicolumn{4}{|c|}{ Model A } & \multicolumn{4}{|c|}{ Model B } \\
\hline & \multicolumn{2}{|c|}{$\begin{array}{c}\text { Team } \\
\text { Delegation }\end{array}$} & \multicolumn{2}{|c|}{$\begin{array}{c}\text { Cash } \\
\text { Profit Sharing }\end{array}$} & \multicolumn{2}{|c|}{$\begin{array}{c}\text { Team } \\
\text { Delegation }\end{array}$} & \multicolumn{2}{|c|}{$\begin{array}{c}\text { Cash } \\
\text { Profit Sharing }\end{array}$} \\
\hline & Coeff. & M. E. & Coeff. & M. E. & Coeff. & M. E. & $\begin{array}{l}\text { Coeff. } \\
1.450^{* * *} \\
(0.198)\end{array}$ & $\begin{array}{l}\text { M. E. } \\
0.512^{* * *} \\
(0.065)\end{array}$ \\
\hline Internal Uncertainty & $\begin{array}{l}0.143 * * * \\
(0.032)\end{array}$ & $\begin{array}{l}0.040 * * * \\
(0.008)\end{array}$ & $\begin{array}{l}0.039 \\
(0.031)\end{array}$ & $\begin{array}{l}0.011 \\
(0.009)\end{array}$ & $\begin{array}{l}0.143 * * * \\
(0.032)\end{array}$ & $\begin{array}{l}0.041 * * * \\
(0.009)\end{array}$ & $\begin{array}{l}-0.030 \\
(0.029)\end{array}$ & $\begin{array}{l}-0.009 \\
(0.009)\end{array}$ \\
\hline External Uncertainty & $\begin{array}{l}-0.031 \\
(0.042)\end{array}$ & $\begin{array}{l}-0.008 \\
(0.012)\end{array}$ & $\begin{array}{l}0.025 \\
(0.042)\end{array}$ & $\begin{array}{l}0.007 \\
(0.012)\end{array}$ & $\begin{array}{l}-0.047 \\
(0.043)\end{array}$ & $\begin{array}{l}-0.013 \\
(0.012)\end{array}$ & $\begin{array}{c}0.036 \\
(0.040)\end{array}$ & $\begin{array}{c}0.011 \\
(0.012)\end{array}$ \\
\hline $\begin{array}{l}\log (\text { pseudo-likelihood }) \\
\rho\end{array}$ & & $\begin{array}{r}-521 \\
0.0 \\
0.0 \\
\end{array}$ & $\begin{array}{l}.62 \\
25 \\
90) \\
\end{array}$ & & & $\begin{array}{r}-50 \\
-0.7 \\
(0 .\end{array}$ & $\begin{array}{l}.96 \\
8 * * * \\
91)\end{array}$ & \\
\hline
\end{tabular}

Table 1d: Team Delegation and Firm-Level Incentives (Cash Profit Sharing)

Table 1e: Individual Delegation (Involvement) and Firm-Level Incentives (Deferred

\begin{tabular}{|c|c|c|c|c|c|c|c|c|}
\hline & \multicolumn{4}{|c|}{ Model A } & \multicolumn{4}{|c|}{ Model B } \\
\hline & \multicolumn{2}{|c|}{$\begin{array}{l}\text { Individual } \\
\text { Delegation }\end{array}$} & \multicolumn{2}{|c|}{$\begin{array}{c}\text { Deferred } \\
\text { Profit Sharing }\end{array}$} & \multicolumn{2}{|c|}{$\begin{array}{l}\text { Individual } \\
\text { Delegation }\end{array}$} & \multicolumn{2}{|c|}{$\begin{array}{c}\text { Deferred } \\
\text { Profit Sharing }\end{array}$} \\
\hline & Coeff. & M. E. & Coeff. & M. E. & Coeff. & M. E. & Coeff. & M. E. \\
\hline Individual Delegation & & & & & & & $\begin{array}{l}0.851 * * * \\
(0.311)\end{array}$ & $\begin{array}{l}0.266 * * * \\
(0.112)\end{array}$ \\
\hline Internal Uncertainty & $\begin{array}{l}0.120 * * * \\
(0.030)\end{array}$ & $\begin{array}{l}0.042 * * * \\
(0.010)\end{array}$ & $\begin{array}{l}-0.006 \\
(0.032)\end{array}$ & $\begin{array}{l}-0.001 \\
(0.008)\end{array}$ & $\begin{array}{l}0.122 * * * \\
(0.029)\end{array}$ & $\begin{array}{l}0.042 * * * \\
(0.010)\end{array}$ & $\begin{array}{l}-0.043 \\
(0.034)\end{array}$ & $\begin{array}{l}-0.012 \\
(0.009)\end{array}$ \\
\hline & $\begin{array}{l}-0.051 \\
(0.040)\end{array}$ & $\begin{array}{l}-0.017 \\
(0.014)\end{array}$ & $\begin{array}{l}-0.154 * * * \\
(0.049)\end{array}$ & $\begin{array}{c}-0.041 * * * \\
(0.012)\end{array}$ & $\begin{array}{l}-0.043 \\
(0.040)\end{array}$ & $\begin{array}{l}-0.015 \\
(0.014)\end{array}$ & $\begin{array}{c}-0.129 * * * \\
(0.049)\end{array}$ & $\begin{array}{c}-0.036^{* * * *} \\
(0.013)\end{array}$ \\
\hline $\begin{array}{l}\text { Log(pseudo-likelihood }) \\
\rho_{12}\end{array}$ & & & $\begin{array}{l}538.19 \\
0.106 \\
0.086)\end{array}$ & & & -0 & $\begin{array}{l}5.76 \\
81 * * * \\
167)\end{array}$ & \\
\hline
\end{tabular}

Profit Sharing)

\section{Notes to Table 1}

1. All estimations include controls for industry (1-digit SIC), industry-level capital-labor ratio (3-digit SIC), and firm characteristics: union status, log of number of employees, log of age, and log of average wage.

2. The first column (Coeff.) represents the beta coefficients and the second column represents marginal effects evaluated at the mean of the independent variables with robust standard errors in parenthesis.

3. $\mathrm{N}=530$.

4. All estimations of Delegation and Team Delegation include also an index of employee participation on various decision-making issues. See text for details. 
$\rho=\operatorname{cov}\left(e_{1}, e_{2}\right)$. Standard error of $\rho$ is in parenthesis. The result of the test of exogeneity $\left(\mathrm{H}_{0}: \rho=0\right)$ is shown with the star symbol. It is based on a Wald test.

6 . $* *=$ significant at the $1 \%$ level, $* *=$ significant at the $5 \%$ level, $*=$ significant at the $10 \%$ level. 
Table 2. Model C - Multivariate Probit

Table 2a: Individual Delegation (Involvement), Monitoring, Internal Labor Markets (Employment Security, Promotions or On-the-Job Training) and Individual-Level Incentives

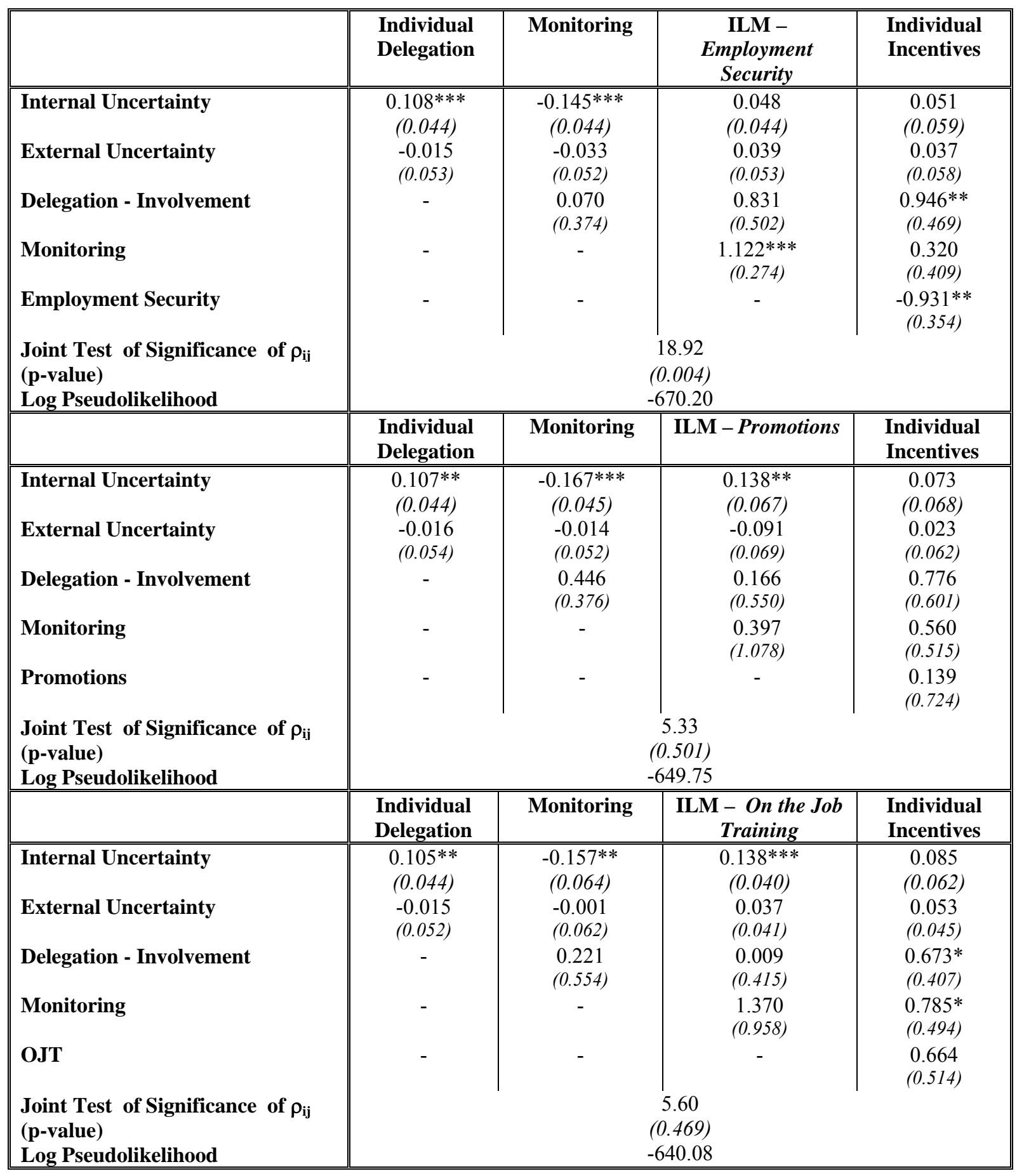


Table 2b: Individual Delegation (Control), Monitoring, Internal Labor Markets (Employment Security,

\begin{tabular}{|c|c|c|c|c|}
\hline & $\begin{array}{l}\text { Individual } \\
\text { Delegation }\end{array}$ & Monitoring & $\begin{array}{c}\text { ILM - } \\
\text { Employment } \\
\text { Security } \\
\end{array}$ & $\begin{array}{l}\text { Individual } \\
\text { Incentives }\end{array}$ \\
\hline IInternal Uncertainty & $\begin{array}{l}0.152 * * * \\
(0.040)\end{array}$ & $\begin{array}{l}-0.129 * * * \\
(0.045)\end{array}$ & $\begin{array}{l}0.055 \\
(0.046)\end{array}$ & $\begin{array}{l}0.070 \\
(0.069)\end{array}$ \\
\hline External Uncertainty & $\begin{array}{c}0.112 * * \\
(0.051)\end{array}$ & $\begin{array}{l}-0.022 \\
(0.050)\end{array}$ & $\begin{array}{l}0.008 \\
(0.054)\end{array}$ & $\begin{array}{c}0.011 \\
(0.058)\end{array}$ \\
\hline Delegation - Control & - & $\begin{array}{l}-0.100 \\
(0.291)\end{array}$ & $\begin{array}{l}0.509 \\
(0.364)\end{array}$ & $\begin{array}{c}0.576 \\
(0.339)\end{array}$ \\
\hline Monitoring & - & - & $\begin{array}{l}1.321 * * * \\
(0.213)\end{array}$ & $\begin{array}{l}0.647 * \\
(0.371)\end{array}$ \\
\hline Employment Security & - & - & - & $\begin{array}{c}-0.745^{*} \\
(0.435)\end{array}$ \\
\hline $\begin{array}{l}\text { Joint Test of Significance of } \rho_{\mathrm{ij}} \\
\text { (p-value) } \\
\text { Log Pseudolikelihood }\end{array}$ & \multicolumn{4}{|c|}{$\begin{array}{r}19.70 \\
(0.003) \\
-689.60\end{array}$} \\
\hline & $\begin{array}{l}\text { Individual } \\
\text { Delegation }\end{array}$ & Monitoring & ILM - Promotions & $\begin{array}{l}\text { Individual } \\
\text { Incentives }\end{array}$ \\
\hline Internal Uncertainty & $\begin{array}{c}0.150 * * * \\
(0.040)\end{array}$ & $\begin{array}{l}-0.159^{* * *} \\
(0.048)\end{array}$ & $\begin{array}{l}0.090 \\
(0.102)\end{array}$ & $\begin{array}{c}0.087 \\
(0.061)\end{array}$ \\
\hline External Uncertainty & $\begin{array}{c}0.115^{* *} \\
(0.051)\end{array}$ & $\begin{array}{l}-0.007 \\
(0.056)\end{array}$ & $\begin{array}{c}-0.109 * \\
(0.070)\end{array}$ & $\begin{array}{l}0.021 \\
(0.063)\end{array}$ \\
\hline Delegation - Control & - & $\begin{array}{l}-0.005 \\
(0.363)\end{array}$ & $\begin{array}{l}-0.030 \\
(0.686)\end{array}$ & $\begin{array}{l}0.419 \\
(0.547)\end{array}$ \\
\hline Monitoring & - & - & $\begin{array}{l}-0.683 \\
(1.307)\end{array}$ & $\begin{array}{c}1.084^{* *} \\
(0.549)\end{array}$ \\
\hline
\end{tabular}




\begin{tabular}{|c|c|c|c|c|}
\hline $\begin{array}{l}\text { Promotions } \\
\text { Joint Test of Significance of } \rho_{\mathrm{ii}} \\
\text { (p-value) } \\
\text { Log Pseudolikelihood }\end{array}$ & - & - & $\begin{array}{l}4.78 \\
0.571) \\
667.12\end{array}$ & $\begin{array}{l}0.696^{*} \\
(0.429)\end{array}$ \\
\hline & $\begin{array}{l}\text { Individual } \\
\text { Delegation }\end{array}$ & Monitoring & $\begin{array}{c}\text { ILM - On the Job } \\
\text { Training }\end{array}$ & $\begin{array}{l}\text { Individual } \\
\text { Incentives }\end{array}$ \\
\hline $\begin{array}{l}\text { Internal Uncertainty } \\
\text { External Uncertainty } \\
\text { Delegation - Control }\end{array}$ & $\begin{array}{c}0.151 * * * \\
(0.040) \\
0.112 * * \\
(0.052) \\
-\end{array}$ & $\begin{array}{c}-0.155^{* * *} \\
(0.048) \\
-0.013 \\
(0.051) \\
0.005\end{array}$ & $\begin{array}{c}0.091 \\
(0.105) \\
0.041 \\
(0.071) \\
-0.244\end{array}$ & $\begin{array}{c}0.086 \\
(0.072) \\
0.009 \\
(0.063) \\
0.416\end{array}$ \\
\hline $\begin{array}{l}\text { Delegation - Control } \\
\text { Monitoring }\end{array}$ & - & $\begin{array}{c}0.005 \\
(0.342) \\
-\end{array}$ & $\begin{array}{l}(0.593) \\
-0.084\end{array}$ & $\begin{array}{c}(0.582) \\
0.913\end{array}$ \\
\hline 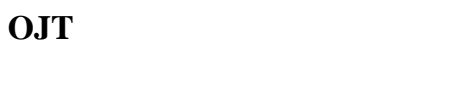 & - & - & - & $\begin{array}{c}1.029 * * * \\
(0.388)\end{array}$ \\
\hline $\begin{array}{l}\text { Joint Test of Significance of } \rho_{\mathrm{ij}} \\
\text { (p-value) } \\
\text { Log Pseudolikelihood }\end{array}$ & & & $\begin{array}{l}3.86 \\
0.694) \\
657.42\end{array}$ & \\
\hline
\end{tabular}


Table 2c: Team Delegation, Monitoring, Internal Labor Markets (Employment Security, Promotions or

\begin{tabular}{|c|c|c|c|c|}
\hline & $\begin{array}{c}\text { Team } \\
\text { Delegation }\end{array}$ & Monitoring & $\begin{array}{c}\text { ILM - } \\
\text { Employment } \\
\text { Security } \\
\end{array}$ & $\begin{array}{l}\text { Group } \\
\text { Bonus }\end{array}$ \\
\hline Internal Uncertainty & $\begin{array}{c}0.151 * * * \\
(0.051)\end{array}$ & $\begin{array}{c}-0.144 * * * \\
(0.045)\end{array}$ & $\begin{array}{c}0.019 \\
(0.071)\end{array}$ & $\begin{array}{c}0.081 \\
(0.073)\end{array}$ \\
\hline External Uncertainty & $\begin{array}{l}0.085 \\
(0.063)\end{array}$ & $\begin{array}{l}-0.027 \\
(0.057)\end{array}$ & $\begin{array}{l}0.027 \\
(0.058)\end{array}$ & $\begin{array}{l}-0.014 \\
(0.057)\end{array}$ \\
\hline Team Delegation & - & $\begin{array}{l}-0.275 \\
(0.468)\end{array}$ & $\begin{array}{l}1.435 \\
(1.285)\end{array}$ & $\begin{array}{l}1.304 \\
(1.180)\end{array}$ \\
\hline Monitoring & - & - & $\begin{array}{c}0.929 \\
(0.892)\end{array}$ & $\begin{array}{c}0.601 \\
(0.645)\end{array}$ \\
\hline $\begin{array}{l}\text { Employment Security } \\
\text { Joint Test of Significance of } \rho_{\mathrm{ij}} \\
\text { (p-value) } \\
\text { Log Pseudolikelihood }\end{array}$ & \multicolumn{4}{|c|}{$\begin{array}{c}14.95 \\
(0.021) \\
-603.97\end{array}$} \\
\hline & $\begin{array}{c}\text { Team } \\
\text { Delegation }\end{array}$ & Monitoring & ILM - Promotions & $\begin{array}{l}\text { Group } \\
\text { Bonus }\end{array}$ \\
\hline Internal Uncertainty & $\begin{array}{c}0.134 * * * \\
(0.051)\end{array}$ & $\begin{array}{c}-0.159 * * * \\
(0.047)\end{array}$ & $\begin{array}{c}0.078 \\
(0.087)\end{array}$ & $\begin{array}{l}0.102 * \\
(0.057)\end{array}$ \\
\hline External Uncertainty & $\begin{array}{l}0.090^{*} \\
(0.060)\end{array}$ & $\begin{array}{l}-0.019 \\
(0.053)\end{array}$ & $\begin{array}{c}-0.127^{* * *} \\
(0.062)\end{array}$ & $\begin{array}{c}0.022 \\
(0.067)\end{array}$ \\
\hline Team Delegation & - & $\begin{array}{l}-0.096 \\
(0.450)\end{array}$ & $\begin{array}{c}1.359^{* *} \\
(0.597)\end{array}$ & $\begin{array}{l}0.779 \\
(0.613)\end{array}$ \\
\hline Monitoring & - & - & $\begin{array}{l}-0.140 \\
(0.603)\end{array}$ & $\begin{array}{l}0.645 \\
(0.563)\end{array}$ \\
\hline Promotions & - & - & - & $\begin{array}{l}0.107 \\
(0.925)\end{array}$ \\
\hline
\end{tabular}




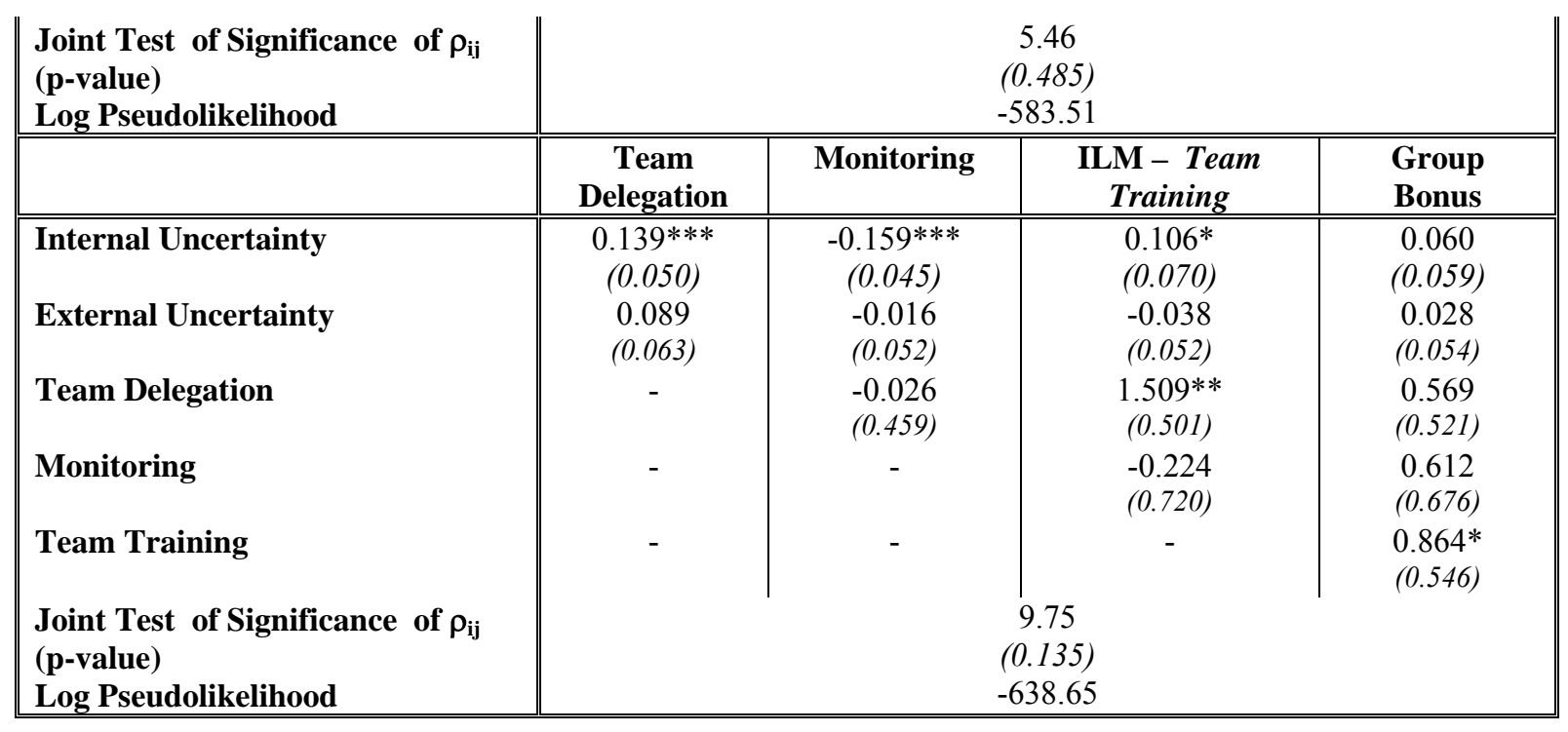


Table 2d: Team Delegation, Monitoring, Internal Labor Markets (Employment Security, Promotions or Team Training), and Firm-level Incentives (Cash Profit Sharing)

\begin{tabular}{|c|c|c|c|c|}
\hline & $\begin{array}{c}\text { Team } \\
\text { Delegation }\end{array}$ & Monitoring & $\begin{array}{l}\text { ILM - } \\
\text { Employment } \\
\text { Security }\end{array}$ & $\begin{array}{c}\text { Cash Profit } \\
\text { Sharing }\end{array}$ \\
\hline Internal Uncertainty & $\begin{array}{c}0.147 * * \\
(0.057)\end{array}$ & $\begin{array}{c}-0.141^{* * * *} \\
(0.049)\end{array}$ & $\begin{array}{c}0.064 \\
(0.079)\end{array}$ & $\begin{array}{c}0.008 \\
(0.048)\end{array}$ \\
\hline External Uncertainty & $\begin{array}{c}0.070 \\
(0.059)\end{array}$ & $\begin{array}{l}-0.036 \\
(0.049)\end{array}$ & $\begin{array}{l}0.040 \\
(0.057)\end{array}$ & $\begin{array}{c}0.043 \\
(0.053)\end{array}$ \\
\hline Team Delegation & - & $\begin{array}{l}0.221 \\
(0.914)\end{array}$ & $\begin{array}{l}0.183 \\
(1.729)\end{array}$ & $\begin{array}{c}0.873 * * \\
(0.426)\end{array}$ \\
\hline Monitoring & - & - & $\begin{array}{l}1.311 * * * \\
(0.297)\end{array}$ & $\begin{array}{l}0.483 * \\
(0.330)\end{array}$ \\
\hline Employment Security & - & - & - & $\begin{array}{l}-0.081 \\
(0.401)\end{array}$ \\
\hline $\begin{array}{l}\text { Joint Test of Significance of } \rho_{\mathrm{ij}} \\
\text { (p-value) } \\
\text { Log Pseudolikelihood }\end{array}$ & \multicolumn{4}{|c|}{$\begin{array}{r}17.84 \\
(0.000) \\
-608.52 \\
\end{array}$} \\
\hline & $\begin{array}{c}\text { Team } \\
\text { Delegation } \\
\end{array}$ & Monitoring & $\begin{array}{c}\text { ILM - } \\
\text { Promotions } \\
\end{array}$ & $\begin{array}{c}\text { Cash Profit } \\
\text { Sharing } \\
\end{array}$ \\
\hline Internal Uncertainty & $\begin{array}{l}0.150 * * * \\
(0.051)\end{array}$ & $\begin{array}{l}-0.162 * * * \\
(0.045)\end{array}$ & $\begin{array}{c}0.082 \\
(0.056)\end{array}$ & $\begin{array}{l}-0.052 \\
(0.046)\end{array}$ \\
\hline External Uncertainty & $\begin{array}{r}0.093^{*} \\
(0.063)\end{array}$ & $\begin{array}{l}-0.028 \\
(0.054)\end{array}$ & $\begin{array}{c}-0.133 * * \\
(0.061)\end{array}$ & $\begin{array}{l}0.062 \\
(0.053)\end{array}$ \\
\hline Team Delegation & - & $\begin{array}{l}0.425 \\
(0.453)\end{array}$ & $\begin{array}{l}0.909 \\
(0.643)\end{array}$ & $\begin{array}{l}0.831^{*} \\
(0.463)\end{array}$ \\
\hline Monitoring & - & - & $\begin{array}{l}-0.198 \\
(0.397)\end{array}$ & $\begin{array}{l}-0.123 \\
(0.387)\end{array}$ \\
\hline Promotions & - & - & - & $\begin{array}{c}0.804 * * \\
(0.346)\end{array}$ \\
\hline \multirow[t]{2}{*}{$\begin{array}{l}\text { Joint Test of Significance of } \rho_{\mathrm{ij}} \\
\text { (p-value) } \\
\text { Log Pseudolikelihood } \\
\end{array}$} & \multicolumn{4}{|c|}{$\begin{array}{c}15.38 \\
(0.017) \\
-585.14 \\
\end{array}$} \\
\hline & $\begin{array}{c}\text { Team } \\
\text { Delegation }\end{array}$ & Monitoring & $\begin{array}{c}\text { ILM } \\
\text { Team Training }\end{array}$ & $\begin{array}{c}\text { Cash Profit } \\
\text { Sharing }\end{array}$ \\
\hline Internal Uncertainty & $\begin{array}{l}0.149 * * * \\
(0.053)\end{array}$ & $\begin{array}{c}-0.165 * * * \\
(0.046)\end{array}$ & $\begin{array}{l}0.168 * * * \\
(0.064)\end{array}$ & $\begin{array}{l}-0.033 \\
(0.110)\end{array}$ \\
\hline External Uncertainty & $\begin{array}{l}0.082 \\
(0.058)\end{array}$ & $\begin{array}{l}-0.027 \\
(0.054)\end{array}$ & $\begin{array}{l}-0.017 \\
(0.069)\end{array}$ & $\begin{array}{l}0.035 \\
(0.051)\end{array}$ \\
\hline Team Delegation & - & $\begin{array}{c}0.410 \\
(0.663)\end{array}$ & $\begin{array}{l}0.434 \\
(1.350)\end{array}$ & $\begin{array}{l}0.967 * * * \\
(0.374)\end{array}$ \\
\hline Monitoring & - & - & $\begin{array}{l}0.509 \\
(0.641)\end{array}$ & $\begin{array}{l}0.189 \\
(0.969)\end{array}$ \\
\hline Team Training & - & - & - & $\begin{array}{c}0.512 \\
(0.955)\end{array}$ \\
\hline $\begin{array}{l}\text { Joint Test of Significance of } \rho_{\mathrm{ij}} \\
\text { (p-value) } \\
\text { Log Pseudolikelihood }\end{array}$ & \multicolumn{4}{|c|}{$\begin{array}{r}10.88 \\
(0.092) \\
-643.37\end{array}$} \\
\hline
\end{tabular}




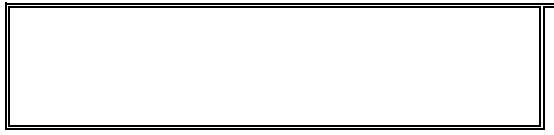

$$
\begin{aligned}
& \text { Individual } \\
& \text { Delegation }
\end{aligned}
$$
Security, Promotions or Team Training), and Firm-level Incentives (Deferred Profit Sharing) 


\begin{tabular}{|c|c|c|c|c|}
\hline $\begin{array}{l}\text { Internal Uncertainty } \\
\text { External Uncertainty }\end{array}$ & $\begin{array}{c}0.109 * * * \\
(0.044) \\
-0.011 \\
(0.053)\end{array}$ & $\begin{array}{c}-0.145 * * * \\
(0.045) \\
-0.026 \\
(0.052)\end{array}$ & $\begin{array}{c}0.044 \\
(0.048) \\
0.051 \\
(0.053)\end{array}$ & $\begin{array}{c}-0.036 \\
(0.059) \\
-0.164 * * * \\
(0.067)\end{array}$ \\
\hline Individual Delegation & - & $\begin{array}{c}0.074 \\
(0.397)\end{array}$ & $\begin{array}{c}0.718 \\
(0.568)\end{array}$ & $\begin{array}{c}0.604 \\
(0.488)\end{array}$ \\
\hline Monitoring & - & - & $\begin{array}{c}1.154 * * * \\
(0.355)\end{array}$ & $\begin{array}{l}-0.041 \\
(0.421)\end{array}$ \\
\hline $\begin{array}{l}\text { Employment Security } \\
\text { Joint Test of Significance of } \rho_{\mathrm{ij}} \\
\text { (p-value) } \\
\text { Log Pseudolikelihood }\end{array}$ & \multicolumn{4}{|c|}{$\begin{array}{c}13.14 \\
(0.041) \\
-656.68\end{array}$} \\
\hline & $\begin{array}{l}\text { Individual } \\
\text { Delegation }\end{array}$ & Monitoring & $\begin{array}{c}\text { ILM - } \\
\text { Promotions }\end{array}$ & $\begin{array}{l}\text { Deferred } \\
\text { Profit } \\
\text { Sharing }\end{array}$ \\
\hline $\begin{array}{l}\text { Internal Uncertainty } \\
\text { External Uncertainty }\end{array}$ & $\begin{array}{c}0.110 * * * \\
(0.044) \\
-0.010 \\
(0.053)\end{array}$ & $\begin{array}{c}-0.163 * * * \\
(0.045) \\
-0.017 \\
(0.053)\end{array}$ & $\begin{array}{c}0.127 * * \\
(0.062) \\
-0.104 * \\
(0.065)\end{array}$ & $\begin{array}{c}-0.072 \\
(0.048) \\
-0.164 * * * \\
(0.068)\end{array}$ \\
\hline Individual Delegation & - & $\begin{array}{c}0.390 \\
(0.371)\end{array}$ & $\begin{array}{l}0.148 \\
(0.581)\end{array}$ & $\begin{array}{c}0.497 \\
(0.659)\end{array}$ \\
\hline Monitoring & - & - & $\begin{array}{c}0.121 \\
(0.642)\end{array}$ & $\begin{array}{l}-0.019 \\
(0.569)\end{array}$ \\
\hline Promotions & - & - & - & $\begin{array}{l}0.341 \\
(0.696)\end{array}$ \\
\hline \multirow[t]{2}{*}{$\begin{array}{l}\text { Joint Test of Significance of } \rho_{\mathrm{ij}} \\
\text { (p-value) } \\
\text { Log Pseudolikelihood } \\
\end{array}$} & \multicolumn{4}{|c|}{$\begin{array}{c}3.19 \\
(0.783) \\
-635.93\end{array}$} \\
\hline & $\begin{array}{l}\text { Individual } \\
\text { Delegation }\end{array}$ & Monitoring & $\begin{array}{c}\text { ILM - On the Job } \\
\text { Training }\end{array}$ & $\begin{array}{l}\text { Deferred } \\
\text { Profit } \\
\text { Sharing }\end{array}$ \\
\hline Internal Uncertainty & $\begin{array}{c}0.109 * * * \\
(0.044)\end{array}$ & $\begin{array}{c}-0.164 * * * \\
(0.044)\end{array}$ & $\begin{array}{c}0.103 \\
(0.073)\end{array}$ & $\begin{array}{l}-0.039 \\
(0.067)\end{array}$ \\
\hline External Uncertainty & $\begin{array}{l}-0.009 \\
(0.053)\end{array}$ & $\begin{array}{l}-0.017 \\
(0.052)\end{array}$ & $\begin{array}{l}0.035 \\
(0.061)\end{array}$ & $\begin{array}{c}-0.170 * * * \\
(0.069)\end{array}$ \\
\hline Individual Delegation & - & $\begin{array}{l}0.387 \\
(0.332)\end{array}$ & $\begin{array}{c}0.049 \\
(0.577)\end{array}$ & $\begin{array}{c}0.539 \\
(0.608)\end{array}$ \\
\hline Monitoring & - & - & $\begin{array}{c}0.441 \\
(0.862)\end{array}$ & $\begin{array}{l}-0.052 \\
(0.508)\end{array}$ \\
\hline $\begin{array}{l}\text { OJT } \\
\text { Joint Test of Significance of } \rho_{\mathrm{ij}}\end{array}$ & \multicolumn{4}{|c|}{$\begin{array}{l}4.026 \\
(0.673) \\
-629.72\end{array}$} \\
\hline
\end{tabular}

\section{Notes to Table 2}

1. All estimations include controls for industry (1-digit SIC), industry-level capital-labor ratio (3-digit SIC), and firm characteristics: union status, log of number of employees, log of age, and log of average wage.

2. Beta coefficients displayed with robust standard errors in parentheses.

3. $\mathrm{N}=530$

4. All estimations of Delegation and Team Delegation include also an index of employee participation on various issues. See text for details.

5. All estimations of Monitoring include the proportion of employees per supervisor. See the text for details. 
6. All estimations of ILM include a dummy indicating the extent to which employees participate in rules related to training and development. See text for details.

7. $* * *=$ significant at the $1 \%$ level, $* *=$ significant at the $5 \%$ level, $*=$ significant at the $10 \%$ level. 
APPENDIX A

Table A1: Variable Definitions, Sources and Summary Statistics

\begin{tabular}{|c|c|c|}
\hline Variable Name & Variable Definition and Source & $\begin{array}{c}\text { Mean } \\
\text { (Std. Err.) } \\
\end{array}$ \\
\hline \multicolumn{3}{|l|}{$\begin{array}{l}\text { Organization design } \\
\text { variables }\end{array}$} \\
\hline $\begin{array}{l}\text { Individual } \\
\text { Incentives }\end{array}$ & $\begin{array}{l}\text { Existence of an individual incentives plan. } 0=\text { no, } 1=\text { yes; from } \\
\text { survey. }\end{array}$ & 0.326 \\
\hline Group level incentives & Existence of group bonus plan. $0=$ no, $1=$ yes; from survey. & 0.239 \\
\hline Firm-level incentives & $\begin{array}{l}\text { Existence of cash or deferred profit sharing plan. } 0=\text { no, } 1=\text { yes; } \\
\text { from survey. }\end{array}$ & 0.386 \\
\hline $\begin{array}{l}\text { Individual delegation - } \\
\text { involvement }\end{array}$ & $\begin{array}{l}\text { The extent to which core employees participate in an employee } \\
\text { involvement program; } 1-5 \text { scale, } 1=\text { not at all, } 5=\text { extreme; from } \\
\text { survey. }\end{array}$ & $\begin{array}{c}3.01 \\
(0.043)\end{array}$ \\
\hline $\begin{array}{l}\text { Individual delegation - } \\
\text { control }\end{array}$ & $\begin{array}{l}\text { The extent to which core employees have control over how their } \\
\text { work is done; } 1-5 \text { scale, } 1=\text { not at all, } 5=\text { extreme; from survey. }\end{array}$ & $\begin{array}{c}3.38 \\
(0.039) \\
\end{array}$ \\
\hline Team delegation & Existence of self-managing work teams. $0=$ no, $1=y e s$; from survey. & $\begin{array}{c}0.232 \\
(0.016)\end{array}$ \\
\hline Monitoring & $\begin{array}{l}\text { The extent to which core employees' work is monitored by their } \\
\text { supervisors; } 1-5 \text { scale, } 1=\text { not at all, } 5=\text { extreme; from survey. }\end{array}$ & $\begin{array}{c}3.42 \\
(0.045) \\
\end{array}$ \\
\hline Guidance & $\begin{array}{l}\text { The extent to which core employees' work is guided and directed by } \\
\text { supervisors and managers. }\end{array}$ & $\begin{array}{c}3.47 \\
(0.044)\end{array}$ \\
\hline Employment security & $\begin{array}{l}\text { Existence of employment security practices. } 0=\text { no, } 1=\text { yes; from } \\
\text { survey. }\end{array}$ & 0.216 \\
\hline On-the-job training & Existence of on-the-job training. $0=$ no, $1=y e s$; from survey. & 0.815 \\
\hline Team training & $\begin{array}{l}\text { Existence of training in team building skills. } 0=\text { no, } 1=\text { yes; from } \\
\text { survey. }\end{array}$ & 0.441 \\
\hline \multicolumn{3}{|l|}{ Uncertainty variables } \\
\hline Complexity & $\begin{array}{l}\text { The extent to which core employees' work tasks are complex; } 1-5 \\
\text { scale, } 1=\text { not at all, } 5=\text { extreme; from survey. }\end{array}$ & $\begin{array}{l}2.93 \\
(0.042)\end{array}$ \\
\hline Variability & $\begin{array}{l}\text { The extent to which core employees' work tasks are variable; } 1-5 \\
\text { scale, } 1=\text { not at all, } 5 \text { = extreme; from survey. }\end{array}$ & $\begin{array}{c}3.22 \\
(0.038)\end{array}$ \\
\hline Routine & $\begin{array}{l}\text { The extent to which core employee's work activities are routine; } 1-5 \\
\text { scale, } 1=\text { not at all, } 5=\text { extreme; from survey. }\end{array}$ & $\begin{array}{c}3.42 \\
(0.037)\end{array}$ \\
\hline Internal uncertainty & $\begin{array}{l}\text { The sum of complexity, variability and reversed-routine scales, } \\
3=\text { not at all, } 15=\text { extreme; from survey }\end{array}$ & $\begin{array}{c}8.73 \\
(0.084)\end{array}$ \\
\hline External uncertainty & $\begin{array}{l}\text { Logarithm of standard deviation of net income; based on } 5 \text { years of } \\
\text { net income in 3-digit SIC industries, 1990-1994; from } \\
\text { COMPUSTAT. }\end{array}$ & $\begin{array}{c}4.84 \\
(0.072)\end{array}$ \\
\hline
\end{tabular}


Table A1

(Continued)

\begin{tabular}{|c|c|c|}
\hline Variable Name & Variable Definition and Source & $\begin{array}{c}\text { Mean } \\
\text { (Std. Err.) }\end{array}$ \\
\hline \multicolumn{3}{|l|}{ Firm characteristics } \\
\hline Firm size & $\begin{array}{l}\text { Total number of employees; from Minnesota Department of } \\
\text { Economic Security. }\end{array}$ & $\begin{array}{c}336.44 \\
(0.575) \\
\operatorname{Min}=19.5 \\
\operatorname{Max}=21422\end{array}$ \\
\hline Firm age & Years in business since establishment; from survey & $\begin{array}{c}3.36 \\
(0.112) \\
\operatorname{Min}=0.2 \\
\operatorname{Max}=14.9\end{array}$ \\
\hline Unionization & Firm's unionization status; $0=$ non-union, $1=$ union; from survey. & 0.177 \\
\hline Capital-labor ratio & $\begin{array}{l}\text { Log of capital-labor ratio (in \$1000's per worker) in 3-digit SIC } \\
\text { industries; from COMPUSTAT }\end{array}$ & $\begin{array}{c}4.75 \\
(0.046)\end{array}$ \\
\hline Log of wage & $\begin{array}{l}\text { Log of firm average wage; from Minnesota Department of Economic } \\
\text { Security }\end{array}$ & $\begin{array}{l}10.15 \\
(0.026)\end{array}$ \\
\hline \multicolumn{3}{|l|}{ Industry } \\
\hline & Mining, Construction & 0.026 \\
\hline & Manufacturing & 0.409 \\
\hline & Transportation & 0.022 \\
\hline & Trade (Wholesale, Retail) & 0.392 \\
\hline & Finance, Insurance & 0.039 \\
\hline & Services & 0.109 \\
\hline \multicolumn{3}{|l|}{ Instruments } \\
\hline Z & Index of participation in decision-making issues & $\begin{array}{c}10.18 \\
(0.185)\end{array}$ \\
\hline Q & \# of employees per supervisor & $\begin{array}{l}10.70 \\
(0.601)\end{array}$ \\
\hline $\mathrm{R}$ & Participation in issues related to personnel development and training & $\begin{array}{l}3.28 \\
(0.055)\end{array}$ \\
\hline
\end{tabular}


APPENDIX B: Replication of Table 2 (Model C) with Guidance instead of Monitoring

Table B1a: Individual Delegation (Involvement), Guidance, Internal Labor Markets (Employment Security, Promotions or On-the-Job Training) and Individual-Level Incentives

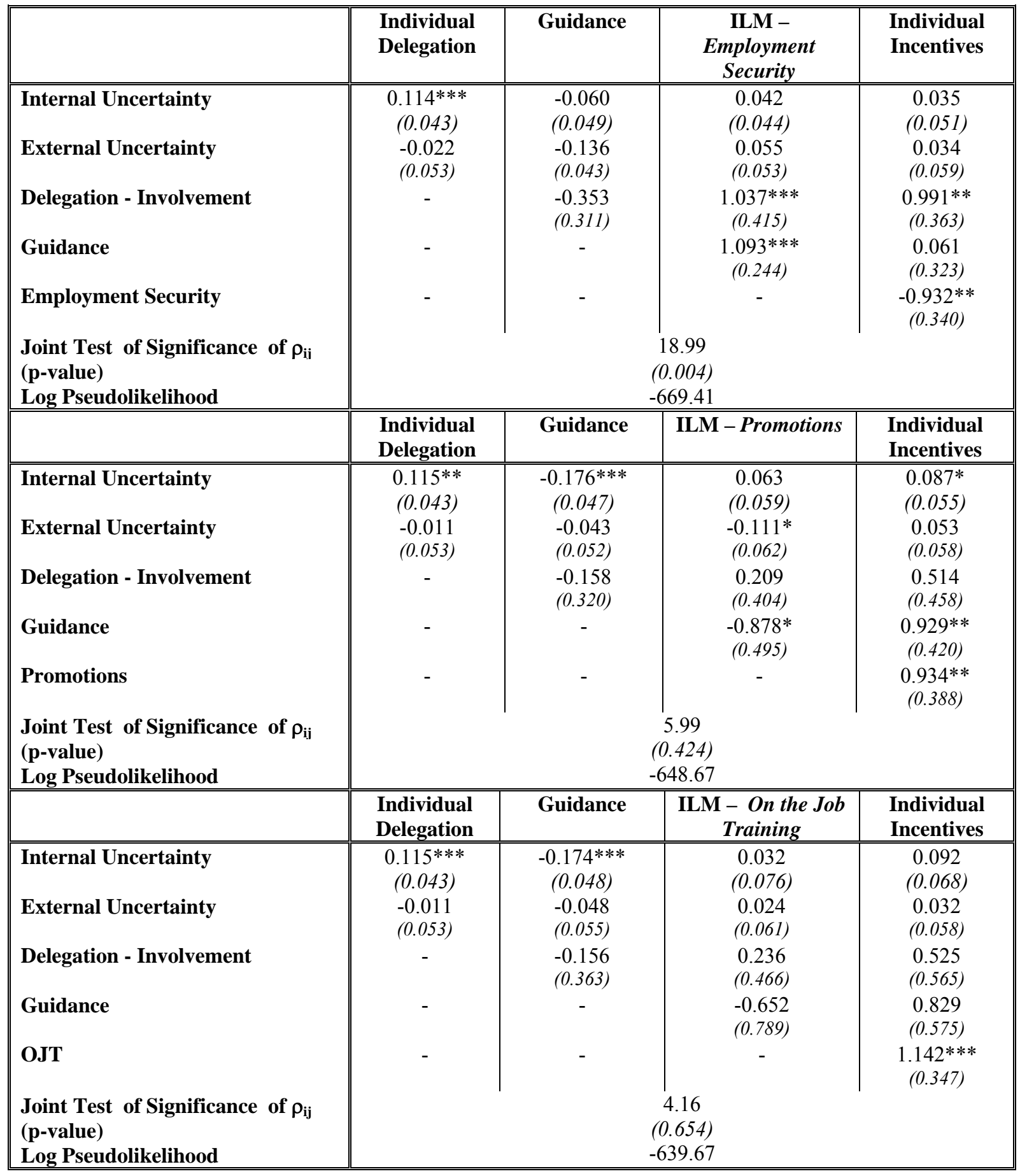


Table B1b: Individual Delegation (Control), Guidance, Internal Labor Markets (Employment Security,

\begin{tabular}{|c|c|c|c|c|}
\hline & $\begin{array}{l}\text { Individual } \\
\text { Delegation }\end{array}$ & Guidance & $\begin{array}{c}\text { ILM - } \\
\text { Employment } \\
\text { Security }\end{array}$ & $\begin{array}{l}\text { Individual } \\
\text { Incentives }\end{array}$ \\
\hline Internal Uncertainty & $\begin{array}{c}0.155^{* * *} \\
(0.040)\end{array}$ & $\begin{array}{c}-0.119 * * * \\
(0.048)\end{array}$ & $\begin{array}{c}0.064 \\
(0.045)\end{array}$ & $\begin{array}{c}0.064 \\
(0.065)\end{array}$ \\
\hline External Uncertainty & $\begin{array}{c}0.117 * * \\
(0.051)\end{array}$ & $\begin{array}{l}-0.031 \\
(0.048)\end{array}$ & $\begin{array}{c}0.028 \\
(0.051)\end{array}$ & $\begin{array}{l}0.017 \\
(0.059)\end{array}$ \\
\hline Delegation - Control & - & $\begin{array}{l}-0.411 \\
(0.308)\end{array}$ & $\begin{array}{l}0.515 \\
(0.369)\end{array}$ & $\begin{array}{c}0.428 \\
(0.491)\end{array}$ \\
\hline Guidance & - & - & $\begin{array}{l}1.346^{* * *} \\
(0.235)\end{array}$ & $\begin{array}{l}0.265 \\
(0.358)\end{array}$ \\
\hline Employment Security & - & - & - & $\begin{array}{c}-0.793 * \\
(0.471)\end{array}$ \\
\hline \multirow[t]{2}{*}{$\begin{array}{l}\text { Joint Test of Significance of } \rho_{\mathrm{ij}} \\
\text { (p-value) } \\
\text { Log Pseudolikelihood }\end{array}$} & \multicolumn{4}{|c|}{$\begin{array}{r}18.36 \\
(0.005) \\
-684.59 \\
\end{array}$} \\
\hline & $\begin{array}{l}\text { Individual } \\
\text { Delegation }\end{array}$ & " Guidance & ILM - Promotions & $\begin{array}{l}\text { Individual } \\
\text { Incentives }\end{array}$ \\
\hline Internal Uncertainty & $\begin{array}{l}0.150 * * * \\
(0.041)\end{array}$ & $\begin{array}{l}-0.169 * * * \\
(0.049)\end{array}$ & $\begin{array}{c}0.062 \\
(0.059)\end{array}$ & $\begin{array}{l}0.092^{*} \\
(0.059)\end{array}$ \\
\hline External Uncertainty & $\begin{array}{c}0.114^{* *} \\
(0.051)\end{array}$ & $\begin{array}{l}-0.028 \\
(0.054)\end{array}$ & $\begin{array}{c}-0.117^{*} \\
(0.064)\end{array}$ & $\begin{array}{c}0.040 \\
(0.067)\end{array}$ \\
\hline Delegation - Control & - & $\begin{array}{l}-0.333 \\
(0.398)\end{array}$ & $\begin{array}{c}0.062 \\
(0.505)\end{array}$ & $\begin{array}{l}0.334 \\
(0.653)\end{array}$ \\
\hline Guidance & - & - & $\begin{array}{l}-0.927 * * * \\
(0.377)\end{array}$ & $\begin{array}{c}1.014 * * \\
(0.367)\end{array}$ \\
\hline
\end{tabular}




\begin{tabular}{|c|c|c|c|c|}
\hline $\begin{array}{l}\text { Promotions } \\
\text { Joint Test of Significance of } \rho_{\mathrm{ii}} \\
\text { (p-value) } \\
\text { Log Pseudolikelihood }\end{array}$ & - & - & $\begin{array}{l}6.96 \\
0.324) \\
660.34\end{array}$ & $\begin{array}{l}0.889^{*} \\
(0.522)\end{array}$ \\
\hline & $\begin{array}{l}\text { Individual } \\
\text { Delegation }\end{array}$ & Guidance & $\begin{array}{c}\text { ILM - On the Job } \\
\text { Training }\end{array}$ & $\begin{array}{l}\text { Individual } \\
\text { Incentives }\end{array}$ \\
\hline $\begin{array}{l}\text { Internal Uncertainty } \\
\text { External Uncertainty }\end{array}$ & $\begin{array}{c}0.150 * * * \\
(0.041) \\
0.111 * * \\
(0.051)\end{array}$ & $\begin{array}{c}-0.165 * * * \\
(0.050) \\
-0.033 \\
(0.058)\end{array}$ & $\begin{array}{c}0.030 \\
(0.074) \\
0.020 \\
(0.072)\end{array}$ & $\begin{array}{c}0.094 \\
(0.064) \\
0.018 \\
(0.062)\end{array}$ \\
\hline Delegation - Control & - & $\begin{array}{l}-0.386 \\
(0.426)\end{array}$ & $\begin{array}{l}-0.048 \\
(0.670)\end{array}$ & $\begin{array}{l}0.407 \\
(0.569)\end{array}$ \\
\hline Guidance & - & - & $\begin{array}{c}-0.843^{*} \\
(0.516)\end{array}$ & $\begin{array}{c}0.985^{* *} \\
(0.436)\end{array}$ \\
\hline OJT & - & - & - & $\begin{array}{c}1.182 * * * \\
(0.328)\end{array}$ \\
\hline $\begin{array}{l}\text { Joint Test of Significance of } \rho_{\mathrm{ij}} \\
\text { (p-value) } \\
\text { Log Pseudolikelihood }\end{array}$ & & & $\begin{array}{l}4.99 \\
0.544) \\
650.57\end{array}$ & \\
\hline
\end{tabular}


Table B1c: Team Delegation, Guidance, Internal Labor Markets (Employment Security, Promotions or

\begin{tabular}{|c|c|c|c|c|}
\hline & $\begin{array}{c}\text { Team } \\
\text { Delegation }\end{array}$ & "Guidance & $\begin{array}{c}\text { ILM - } \\
\text { Employment } \\
\text { Security } \\
\end{array}$ & $\begin{array}{l}\text { Group } \\
\text { Bonus }\end{array}$ \\
\hline Internal Uncertainty & $\begin{array}{c}0.152 * * * \\
(0.051)\end{array}$ & $\begin{array}{c}-0.141^{* * *} \\
(0.051)\end{array}$ & $\begin{array}{l}0.025 \\
(0.064)\end{array}$ & $\begin{array}{c}0.077 \\
(0.074)\end{array}$ \\
\hline External Uncertainty & $\begin{array}{c}0.076 \\
(0.057)\end{array}$ & $\begin{array}{l}-0.039 \\
(0.053)\end{array}$ & $\begin{array}{l}0.035 \\
(0.054)\end{array}$ & $\begin{array}{r}0.016 \\
(0.061)\end{array}$ \\
\hline Team Delegation & - & $\begin{array}{l}-0.628 \\
(0.743)\end{array}$ & $\begin{array}{l}1.521 \\
(1.068)\end{array}$ & $\begin{array}{c}1.336 \\
(0.957)\end{array}$ \\
\hline Guidance & - & - & $\begin{array}{c}0.997 \\
(0.605)\end{array}$ & $\begin{array}{c}0.464 \\
(0.566)\end{array}$ \\
\hline $\begin{array}{l}\text { Employment Security } \\
\text { Joint Test of Significance of } \rho_{\mathrm{ij}} \\
(\text {-value) } \\
\text { Log Pseudolikelihood }\end{array}$ & \multicolumn{4}{|c|}{$\begin{array}{c}16.14 \\
(0.014) \\
-602.24\end{array}$} \\
\hline & $\begin{array}{c}\text { Team } \\
\text { Delegation }\end{array}$ & "Guidance & ILM - Promotions & $\begin{array}{l}\text { Group } \\
\text { Bonus }\end{array}$ \\
\hline Internal Uncertainty & $\begin{array}{c}0.133 * * * \\
(0.051)\end{array}$ & $\begin{array}{c}-0.187 * * * \\
(0.043)\end{array}$ & $\begin{array}{c}0.035 \\
(0.066) \\
-0.130 * *\end{array}$ & $\begin{array}{c}0.104 * * \\
(0.050) \\
0.037\end{array}$ \\
\hline External Uncertainty & $\begin{array}{l}0.094^{*} \\
(0.059)\end{array}$ & $\begin{array}{l}-0.042 \\
(0.053)\end{array}$ & $\begin{array}{c}-0.130^{* *} \\
(0.058)\end{array}$ & $\begin{array}{c}0.037 \\
(0.064)\end{array}$ \\
\hline Team Delegation & - & $\begin{array}{c}0.169 \\
(0.380)\end{array}$ & $\begin{array}{c}1.311 * * * \\
(0.462)\end{array}$ & $\begin{array}{l}0.817^{*} \\
(0.439)\end{array}$ \\
\hline Guidance & - & - & $\begin{array}{l}-0.594 \\
(0.441)\end{array}$ & $\begin{array}{l}0.755^{*} \\
(0.413)\end{array}$ \\
\hline Promotions & - & - & - & $\begin{array}{l}0.465 \\
(0.669)\end{array}$ \\
\hline
\end{tabular}




\begin{tabular}{|c|c|c|c|c|}
\hline \multirow[t]{2}{*}{$\begin{array}{l}\text { Joint Test of Significance of } \rho_{\mathrm{ij}} \\
\text { (p-value) } \\
\text { Log Pseudolikelihood }\end{array}$} & \multicolumn{4}{|c|}{$\begin{array}{c}7.08 \\
(0.313) \\
-581.53 \\
\end{array}$} \\
\hline & $\begin{array}{c}\text { Team } \\
\text { Delegation }\end{array}$ & Guidance & $\begin{array}{c}\text { ILM - Team } \\
\text { Training }\end{array}$ & $\begin{array}{l}\text { Group } \\
\text { Bonus }\end{array}$ \\
\hline Internal Uncertainty & $\begin{array}{c}0.138 * * * \\
(0.050)\end{array}$ & $\begin{array}{c}-0.183 * * * \\
(0.045)\end{array}$ & $\begin{array}{l}0.097 * \\
(0.060)\end{array}$ & $\begin{array}{c}0.068 \\
(0.056)\end{array}$ \\
\hline External Uncertainty & $\begin{array}{l}0.089 * \\
(0.060)\end{array}$ & $\begin{array}{l}-0.035 \\
(0.052)\end{array}$ & $\begin{array}{l}-0.038 \\
(0.051)\end{array}$ & $\begin{array}{c}0.031 \\
(0.054)\end{array}$ \\
\hline Team Delegation & - & $\begin{array}{c}-0.023 \\
(0.438)\end{array}$ & $\begin{array}{c}1.509 * * \\
(0.501)\end{array}$ & $\begin{array}{l}0.593^{*} \\
(0.397)\end{array}$ \\
\hline Guidance & - & - & $\begin{array}{c}0.112 \\
(0.504)\end{array}$ & $\begin{array}{l}0.636^{*} \\
(0.369)\end{array}$ \\
\hline Team Training & - & - & - & $\begin{array}{l}0.846^{*} \\
(0.447)\end{array}$ \\
\hline $\begin{array}{l}\text { Joint Test of Significance of } \rho_{\mathrm{ij}} \\
\text { (p-value) } \\
\text { Log Pseudolikelihood }\end{array}$ & \multicolumn{4}{|c|}{$\begin{array}{l}10.46 \\
(0.106) \\
-637.41\end{array}$} \\
\hline
\end{tabular}


Table B1d: Team Delegation, Guidance, Internal Labor Markets (Employment Security, Promotions or Team Training), and Firm-level Incentives (Cash Profit Sharing)

\begin{tabular}{|c|c|c|c|c|}
\hline & $\begin{array}{c}\text { Team } \\
\text { Delegation }\end{array}$ & Guidance & $\begin{array}{l}\text { ILM - } \\
\text { Employment } \\
\text { Security }\end{array}$ & $\begin{array}{c}\text { Cash Profit } \\
\text { Sharing }\end{array}$ \\
\hline Internal Uncertainty & $\begin{array}{c}0.168 * * * \\
(0.054)\end{array}$ & $\begin{array}{l}-0.145^{* * *} \\
(0.074)\end{array}$ & $\begin{array}{c}0.026 \\
(0.083)\end{array}$ & $\begin{array}{l}-0.034 \\
(0.104)\end{array}$ \\
\hline External Uncertainty & $\begin{array}{l}0.069 \\
(0.084)\end{array}$ & $\begin{array}{l}-0.041 \\
(0.053)\end{array}$ & $\begin{array}{l}0.032 \\
(0.066)\end{array}$ & $\begin{array}{l}0.037 \\
(0.060)\end{array}$ \\
\hline Team Delegation & - & $\begin{array}{l}-0.454 \\
(0.531)\end{array}$ & $\begin{array}{l}1.360 \\
(1.407)\end{array}$ & $\begin{array}{c}0.808 \\
(1.828)\end{array}$ \\
\hline Guidance & - & - & $\begin{array}{c}0.982 \\
(1.022)\end{array}$ & $\begin{array}{l}-0.267 \\
(2.086)\end{array}$ \\
\hline Employment Security & - & - & - & $\begin{array}{l}-0.036 \\
(1.045)\end{array}$ \\
\hline $\begin{array}{l}\text { Joint Test of Significance of } \rho_{\mathrm{ij}} \\
\text { (p-value) } \\
\text { Log Pseudolikelihood }\end{array}$ & \multicolumn{4}{|c|}{$\begin{array}{r}17.82 \\
(0.007) \\
-606.98 \\
\end{array}$} \\
\hline & $\begin{array}{c}\text { Team } \\
\text { Delegation } \\
\end{array}$ & Guidance & $\begin{array}{c}\text { ILM - } \\
\text { Promotions }\end{array}$ & $\begin{array}{c}\text { Cash Profit } \\
\text { Sharing } \\
\end{array}$ \\
\hline $\begin{array}{l}\text { Internal Uncertainty } \\
\text { External Uncertainty }\end{array}$ & $\begin{array}{c}0.152 * * * \\
(0.053) \\
0.073 \\
(0.054)\end{array}$ & $\begin{array}{c}-0.176^{* * *} \\
(0.048) \\
-0.060 \\
(0.056)\end{array}$ & $\begin{array}{c}0.068 \\
(0.060) \\
-0.133^{* *} \\
(0.059)\end{array}$ & $\begin{array}{c}-0.076 \\
(0.056) \\
0.048 \\
(0.053)\end{array}$ \\
\hline Team Delegation & - & $\begin{array}{l}-0.004 \\
(0.604)\end{array}$ & $\begin{array}{c}1.334 * * \\
(0.598)\end{array}$ & $\begin{array}{l}0.568 \\
(0.473)\end{array}$ \\
\hline Guidance & - & - & $\begin{array}{l}-0.078 \\
(0.597)\end{array}$ & $\begin{array}{l}-0.704 \\
(0.848)\end{array}$ \\
\hline Promotions & - & - & - & $\begin{array}{l}0.578 \\
(0.577)\end{array}$ \\
\hline $\begin{array}{l}\text { Joint Test of Significance of } \rho_{\mathrm{ij}} \\
\text { (p-value) } \\
\text { Log Pseudolikelihood }\end{array}$ & \multicolumn{4}{|c|}{$\begin{array}{c}18.11 \\
(0.017) \\
-582.18 \\
\end{array}$} \\
\hline & $\begin{array}{c}\text { Team } \\
\text { Delegation }\end{array}$ & Guidance & $\begin{array}{c}\text { ILM } \\
\text { Team Training }\end{array}$ & $\begin{array}{c}\text { Cash Profit } \\
\text { Sharing }\end{array}$ \\
\hline Internal Uncertainty & $\begin{array}{l}0.151 * * * \\
(0.055)\end{array}$ & $\begin{array}{c}-0.177 * * * \\
(0.047)\end{array}$ & $\begin{array}{c}0.142 * * * \\
(0.059)\end{array}$ & $\begin{array}{l}-0.084 \\
(0.065)\end{array}$ \\
\hline External Uncertainty & $\begin{array}{c}0.076 \\
(0.060)\end{array}$ & $\begin{array}{l}-0.051 \\
(0.059)\end{array}$ & $\begin{array}{l}-0.031 \\
(0.055)\end{array}$ & $\begin{array}{c}0.031 \\
(0.059)\end{array}$ \\
\hline Team Delegation & - & $\begin{array}{l}-0.088 \\
(0.587)\end{array}$ & $\begin{array}{l}1.439 * \\
(0.898)\end{array}$ & $\begin{array}{l}0.324 \\
(0.663)\end{array}$ \\
\hline Guidance & - & - & $\begin{array}{l}0.648 \\
(0.457)\end{array}$ & $\begin{array}{l}-0.752 \\
(0.811)\end{array}$ \\
\hline Team Training & - & - & - & $\begin{array}{l}0.634 \\
(0.854)\end{array}$ \\
\hline $\begin{array}{l}\text { Joint Test of Significance of } \rho_{\mathrm{ij}} \\
\text { (p-value) } \\
\text { Log Pseudolikelihood }\end{array}$ & \multicolumn{4}{|c|}{$\begin{array}{c}10.70 \\
(0.098) \\
-642.29\end{array}$} \\
\hline
\end{tabular}


Table B1e: Team Delegation, Guidance, Internal Labor Markets (Employment Security, Promotions or Team Training), and Firm-level Incentives (Deferred Profit Sharing)

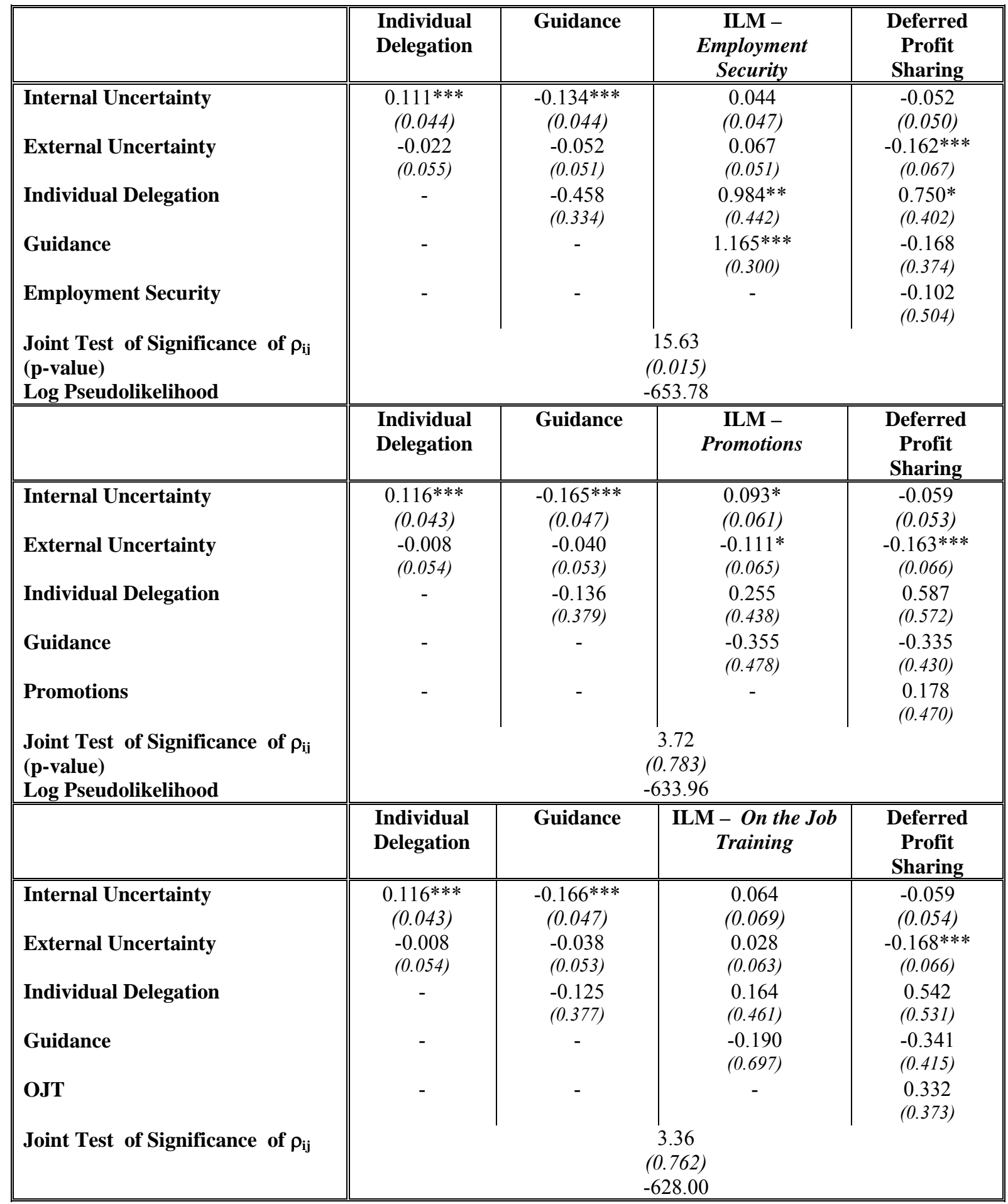




\section{Notes to Table B}

1. All estimations include controls for industry (1-digit SIC), industry-level capital-labor ratio (3-digit SIC), and firm characteristics: union status, log of number of employees, log of age, and log of average wage.

2. Beta coefficients displayed with robust standard errors in parentheses.

3. $\mathrm{N}=530$

4. All estimations of Delegation and Team Delegation include also an index of employee participation on various issues. See text for details.

5. All estimations of Monitoring include the proportion of employees per supervisor. See the text for details.

6. All estimations of ILM include a dummy indicating the extent to which employees participate in rules related to training and development. See text for details.

7. $* * *=$ significant at the $1 \%$ level, $* *=$ significant at the $5 \%$ level, $*=$ significant at the $10 \%$ level. 
APPENDIX C

Table C1a: Uncertainty, Delegation as Involvement and Individual Incentives ${ }^{a}$

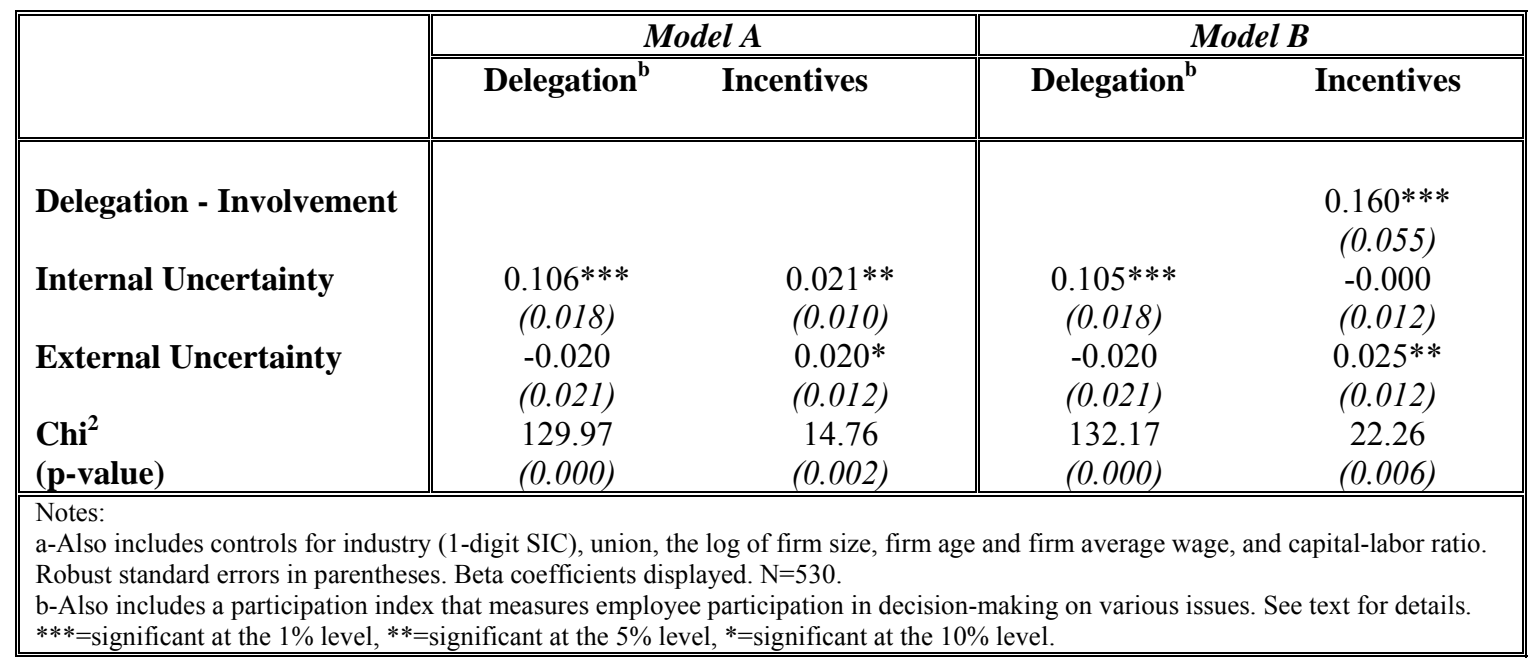

\section{SLS Estimations}

Table C1b: Uncertainty, Delegation as Control and Individual Incentives ${ }^{\mathrm{a}}$

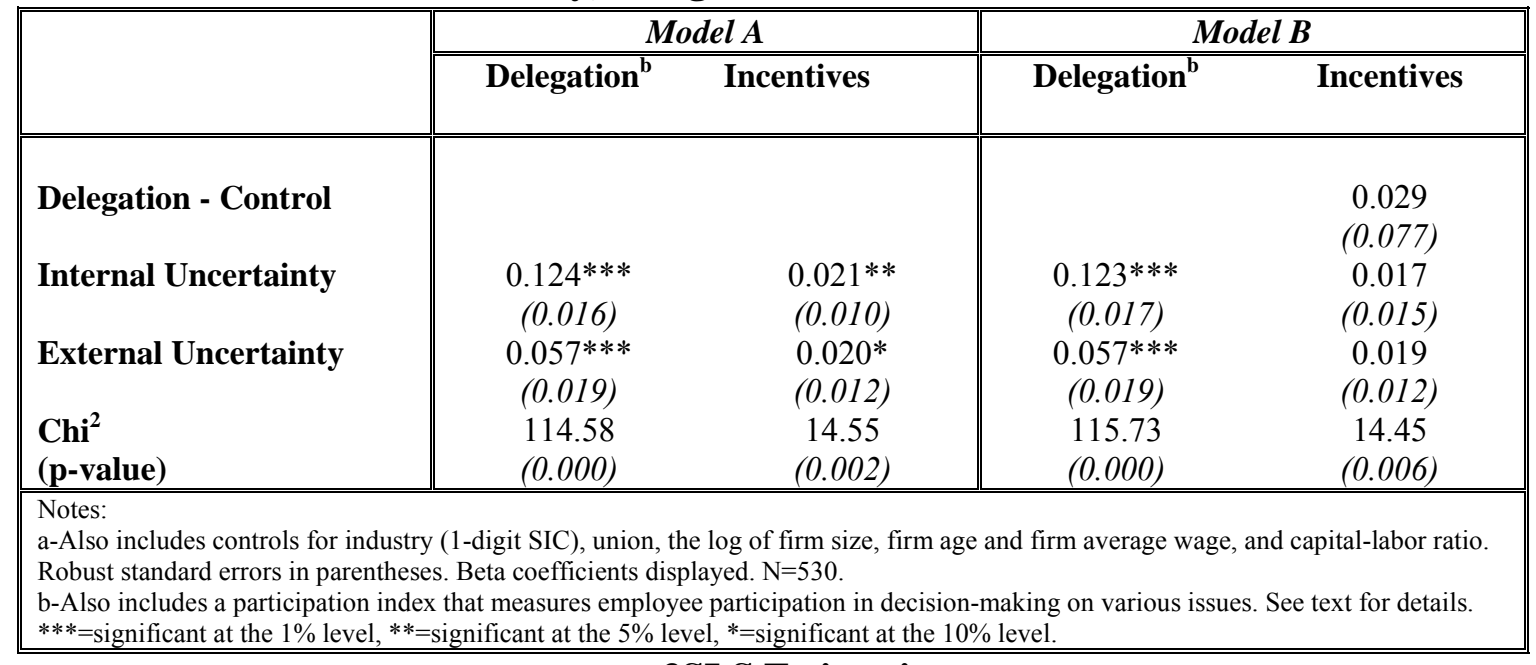

\section{SLS Estimations}


Table C1c: Uncertainty, Team Delegation and Group/Firm Incentives ${ }^{\mathrm{a}}$

\begin{tabular}{|c|c|c|c|c|}
\hline & \multicolumn{2}{|c|}{ Model A } & \multicolumn{2}{|c|}{ Model B } \\
\hline & $\begin{array}{c}\text { Team } \\
\text { Delegation }^{\mathrm{b}} \\
\end{array}$ & Incentives & $\begin{array}{c}\text { Team } \\
\text { Delegation }^{\text {b }} \\
\end{array}$ & Incentives \\
\hline $\begin{array}{l}\text { Team Delegation } \\
\text { Internal Uncertainty } \\
\text { External Uncertainty } \\
\text { Chi }^{2} \\
\text { (p-value) }\end{array}$ & $\begin{array}{c}0.036 * * * \\
(0.008) \\
0.002 \\
(0.009) \\
83.68 \\
(0.000) \\
\end{array}$ & $\begin{array}{c}0.016^{*} \\
(0.009) \\
-0.000 \\
(0.011) \\
8.05 \\
(0.044) \\
\end{array}$ & $\begin{array}{c}0.036^{* * *} \\
(0.008) \\
0.002 \\
(0.009) \\
85.19 \\
(0.000) \\
\end{array}$ & $\begin{array}{c}0.532 * * * \\
(0.137) \\
-0.009 \\
(0.012) \\
-0.000 \\
(0.011) \\
22.11 \\
(0.000) \\
\end{array}$ \\
\hline $\begin{array}{l}\text { Team Delegation } \\
\text { Internal Uncertainty } \\
\text { External Uncertainty } \\
\text { Chi }^{2} \\
\text { (p-value) }\end{array}$ & $\begin{array}{c}0.036 * * * \\
(0.008) \\
0.002 \\
(0.009) \\
84.85 \\
(0.000) \\
\end{array}$ & $\begin{array}{c}0.013 \\
(0.009) \\
0.001 \\
(0.011) \\
4.47 \\
(0.215) \\
\end{array}$ & $\begin{array}{c}0.036 * * * \\
(0.008) \\
0.002 \\
(0.009) \\
92.11 \\
(0.000) \\
\end{array}$ & $\begin{array}{c}0.712 * * * \\
(0.142) \\
-0.021 * * * \\
(0.012) \\
0.002 \\
(0.012) \\
28.41 \\
(0.000) \\
\end{array}$ \\
\hline $\begin{array}{l}\text { Individual Delegation } \\
\text { Internal Uncertainty } \\
\text { External Uncertainty } \\
\text { Chi }^{2} \\
\text { (p-value) }\end{array}$ & $\begin{array}{c}0.105 * * * \\
(0.018) \\
-0.020 \\
(0.021) \\
137.40 \\
(0.000)\end{array}$ & $\begin{array}{c}-0.001 \\
(0.008) \\
-0.037 * * \\
(0.010) \\
15.43 \\
(0.001)\end{array}$ & $\begin{array}{c}0.105 * * * \\
(0.012) \\
-0.020 \\
(0.021) \\
134.48 \\
(0.000)\end{array}$ & $\begin{array}{c}0.133 * * * \\
(0.048) \\
-0.020 * * * \\
(0.011) \\
-0.029 * * * \\
(0.014) \\
21.66 \\
(0.000)\end{array}$ \\
\hline $\begin{array}{l}\text { Notes: } \\
\text { a-Also includes controls for in } \\
\text { ratio. Robust standard errors i } \\
\text { b-Also includes a participation } \\
* * *=\text { significant at the } 1 \% \text { leve }\end{array}$ & $\begin{array}{l}\text {-digit SIC), uni } \\
\text { eses. Beta coef } \\
\text { at measures em } \\
\text { nificant at the 5 }\end{array}$ & $\begin{array}{l}\text { of firm size, } \\
\text { layed. } \mathrm{N}=53 \\
\text { ticipation in } \\
\text { =significant }\end{array}$ & $\begin{array}{l}\text { dirm average } \\
\text { aking on various } \\
\text { evel. }\end{array}$ & d capital-labor \\
\hline
\end{tabular}


Table C2a: Uncertainty, Individual Incentives, Monitoring and Internal Labor Market ${ }^{\mathrm{a}}$ 3SLS Estimations

\begin{tabular}{|c|c|c|c|c|}
\hline & $\begin{array}{l}\text { Individual } \\
\text { Delegation }\end{array}$ & Monitoring & $\begin{array}{c}\text { ILM - } \\
\text { Employment } \\
\text { Security } \\
\end{array}$ & $\begin{array}{l}\text { Individual } \\
\text { Incentives }\end{array}$ \\
\hline Internal Uncertainty & $\begin{array}{l}0.112 * * * \\
(0.028)\end{array}$ & $\begin{array}{l}-0.103 * * * \\
(0.029)\end{array}$ & $\begin{array}{l}-0.017 \\
(0.019)\end{array}$ & $\begin{array}{l}-0.030 \\
(0.022)\end{array}$ \\
\hline External Uncertainty & $\begin{array}{l}0.001 \\
(0.029)\end{array}$ & $\begin{array}{c}0.030 \\
(0.025)\end{array}$ & $\begin{array}{l}0.018 \\
(0.014)\end{array}$ & $\begin{array}{l}0.040 \\
(0.019)\end{array}$ \\
\hline Delegation - Involvement & - & $\begin{array}{l}-0.028 \\
(0.121)\end{array}$ & $\begin{array}{c}0.245 * * * \\
(0.098)\end{array}$ & $\begin{array}{l}0.442 * * * \\
(0.086)\end{array}$ \\
\hline Monitoring & - & - & $\begin{array}{c}0.127 \\
(0.093)\end{array}$ & $\begin{array}{c}0.054 \\
(0.132)\end{array}$ \\
\hline Employment Security & - & - & - & $\begin{array}{c}-1.203 * * * \\
(0.261)\end{array}$ \\
\hline \multirow[t]{2}{*}{$\begin{array}{l}\mathrm{Chi}^{2} \\
\text { (p-value) }\end{array}$} & $\begin{array}{l}52.53 \\
(0.000)\end{array}$ & $\begin{array}{l}25.91 \\
(0.000)\end{array}$ & $\begin{array}{l}15.21 \\
(0.000)\end{array}$ & $\begin{array}{c}38.43 \\
(0.000)\end{array}$ \\
\hline & $\begin{array}{l}\text { Individual } \\
\text { Delegation }\end{array}$ & Monitoring & ILM - Promotions & $\begin{array}{l}\text { Individual } \\
\text { Incentives }\end{array}$ \\
\hline Internal Uncertainty & $\begin{array}{c}0.115 * * * \\
(0.028)\end{array}$ & $\begin{array}{l}-0.104 * * * \\
(0.029)\end{array}$ & $\begin{array}{l}-0.014 \\
(0.019)\end{array}$ & $\begin{array}{l}-0.004 \\
(0.019)\end{array}$ \\
\hline External Uncertainty & $\begin{array}{c}0.001 \\
(0.029)\end{array}$ & $\begin{array}{l}0.031 \\
(0.025)\end{array}$ & $\begin{array}{l}0.000 \\
(0.014)\end{array}$ & $\begin{array}{l}0.027 \\
(0.017)\end{array}$ \\
\hline Delegation - Involvement & - & $\begin{array}{l}-0.027 \\
(0.121)\end{array}$ & $\begin{array}{l}0.339 * * * \\
(0.106)\end{array}$ & $\begin{array}{l}0.119 \\
(0.081)\end{array}$ \\
\hline Monitoring & - & - & $\begin{array}{c}0.063 \\
(0.088)\end{array}$ & $\begin{array}{l}0.064 \\
(0.125)\end{array}$ \\
\hline Promotions & - & - & - & $\begin{array}{c}0.483 * * \\
(0.235)\end{array}$ \\
\hline \multirow[t]{2}{*}{$\begin{array}{l}\mathrm{Chi}^{2} \\
\text { (p-value) } \\
\end{array}$} & $\begin{array}{c}47.45 \\
(0.000) \\
\end{array}$ & $\begin{array}{c}24.93 \\
(0.000) \\
\end{array}$ & $\begin{array}{c}28.52 \\
(0.000) \\
\end{array}$ & $\begin{array}{c}20.41 \\
(0.000) \\
\end{array}$ \\
\hline & $\begin{array}{l}\text { Individual } \\
\text { Delegation }\end{array}$ & Monitoring & $\begin{array}{c}\text { ILM - On the Job } \\
\text { Training }\end{array}$ & $\begin{array}{l}\text { Individual } \\
\text { Incentives }\end{array}$ \\
\hline Internal Uncertainty & $\begin{array}{l}0.110 * * * \\
(0.028)\end{array}$ & $\begin{array}{l}-0.104 * * * \\
(0.029)\end{array}$ & $\begin{array}{l}0.018 \\
(0.022)\end{array}$ & $\begin{array}{c}0.009 \\
(0.020)\end{array}$ \\
\hline External Uncertainty & $\begin{array}{l}0.001 \\
(0.029)\end{array}$ & $\begin{array}{l}0.030 \\
(0.025)\end{array}$ & $\begin{array}{c}0.012 \\
(0.012)\end{array}$ & $\begin{array}{l}0.010 \\
(0.019)\end{array}$ \\
\hline Delegation - Involvement & - & $\begin{array}{l}-0.023 \\
(0.121)\end{array}$ & $\begin{array}{c}0.131 \\
(0.091)\end{array}$ & $\begin{array}{l}-0.080 \\
(0.099)\end{array}$ \\
\hline Monitoring & - & - & $\begin{array}{c}0.112 \\
(0.082)\end{array}$ & $\begin{array}{c}0.031 \\
(0.125)\end{array}$ \\
\hline OJT & - & - & - & $\begin{array}{c}1.115^{* * *} \\
(0.312)\end{array}$ \\
\hline $\begin{array}{l}\mathrm{Chi}^{2} \\
\text { (p-value) }\end{array}$ & $\begin{array}{c}55.17 \\
(0.000) \\
\end{array}$ & $\begin{array}{c}24.83 \\
(0.026) \\
\end{array}$ & $\begin{array}{c}35.52 \\
(0.000) \\
\end{array}$ & $\begin{array}{c}23.83 \\
(0.000) \\
\end{array}$ \\
\hline
\end{tabular}


Table C2b: Uncertainty, Individual Incentives, Monitoring and Internal Labor Market ${ }^{\mathrm{a}}$

\begin{tabular}{|c|c|c|c|c|}
\hline & $\begin{array}{l}\text { Individual } \\
\text { Delegation }\end{array}$ & Monitoring & $\begin{array}{c}\text { ILM - } \\
\text { Employment } \\
\text { Security } \\
\end{array}$ & $\begin{array}{l}\text { Individual } \\
\text { Incentives }\end{array}$ \\
\hline Internal Uncertainty & $\begin{array}{c}0.137 * * * \\
(0.024)\end{array}$ & $\begin{array}{l}-0.164 * * * \\
(0.040)\end{array}$ & $\begin{array}{l}-0.074 * * * \\
(0.026)\end{array}$ & $\begin{array}{c}0.042 \\
(0.035)\end{array}$ \\
\hline External Uncertainty & $\begin{array}{l}0.078 * * * \\
(0.026)\end{array}$ & $\begin{array}{l}-0.000 \\
(0.039)\end{array}$ & $\begin{array}{l}-0.011 \\
(0.016)\end{array}$ & $\begin{array}{l}0.051 \\
(0.045)\end{array}$ \\
\hline Delegation - Control & - & $\begin{array}{c}0.367 * * \\
(0.157)\end{array}$ & $\begin{array}{c}0.471 * * * \\
(0.149)\end{array}$ & $\begin{array}{l}0.609 * * * \\
(0.125)\end{array}$ \\
\hline Monitoring & - & - & $\begin{array}{l}-0.045 \\
(0.098)\end{array}$ & $\begin{array}{l}-0.159 \\
(0.140)\end{array}$ \\
\hline Employment Security & - & - & - & $\begin{array}{l}-1.161 * * * \\
(0.284)\end{array}$ \\
\hline \multirow[t]{2}{*}{$\begin{array}{l}\mathrm{Chi}^{2} \\
\text { (p-value) }\end{array}$} & $\begin{array}{c}63.56 \\
(0.000) \\
\end{array}$ & $\begin{array}{c}30.42 \\
(0.026) \\
\end{array}$ & $\begin{array}{c}23.66 \\
(0.000) \\
\end{array}$ & $\begin{array}{c}32.84 \\
(0.000) \\
\end{array}$ \\
\hline & $\begin{array}{l}\text { Individual } \\
\text { Delegation } \\
\end{array}$ & Monitoring & ILM - Promotions & $\begin{array}{l}\text { Individual } \\
\text { Incentives } \\
\end{array}$ \\
\hline Internal Uncertainty & $\begin{array}{l}0.134 * * * \\
(0.024)\end{array}$ & $\begin{array}{l}-0.160 * * * \\
(0.034)\end{array}$ & $\begin{array}{c}0.009 \\
(0.023)\end{array}$ & $\begin{array}{l}-0.004 \\
(0.024)\end{array}$ \\
\hline External Uncertainty & $\begin{array}{c}0.078 * * * \\
(0.026)\end{array}$ & $\begin{array}{l}-0.002 \\
(0.029)\end{array}$ & $\begin{array}{l}-0.008 \\
(0.013)\end{array}$ & $\begin{array}{l}0.025 \\
(0.019)\end{array}$ \\
\hline Delegation - Control & - & $\begin{array}{c}0.343 * * \\
(0.158)\end{array}$ & $\begin{array}{l}0.086 \\
(0.109)\end{array}$ & $\begin{array}{l}0.064 \\
(0.095)\end{array}$ \\
\hline Monitoring & - & - & $\begin{array}{c}0.018 \\
(0.090)\end{array}$ & $\begin{array}{l}0.062 \\
(0.135)\end{array}$ \\
\hline Promotions & - & - & - & $\begin{array}{l}0.705 * * * \\
(0.204)\end{array}$ \\
\hline \multirow[t]{2}{*}{$\begin{array}{l}\mathrm{Chi}^{2} \\
\text { (p-value) }\end{array}$} & $\begin{array}{c}68.96 \\
(0.000) \\
\end{array}$ & $\begin{array}{c}29.56 \\
(0.000) \\
\end{array}$ & $\begin{array}{c}13.61 \\
(0.000) \\
\end{array}$ & $\begin{array}{c}20.83 \\
(0.000) \\
\end{array}$ \\
\hline & $\begin{array}{l}\text { Individual } \\
\text { Delegation } \\
\end{array}$ & Monitoring & $\begin{array}{c}\text { ILM - On the Job } \\
\text { Training }\end{array}$ & $\begin{array}{l}\text { Individual } \\
\text { Incentives } \\
\end{array}$ \\
\hline Internal Uncertainty & $\begin{array}{c}0.134 * * * \\
(0.025)\end{array}$ & $\begin{array}{l}-0.161 \\
(0.035)\end{array}$ & $\begin{array}{l}0.018 \\
(0.022)\end{array}$ & $\begin{array}{c}0.027 \\
(0.026)\end{array}$ \\
\hline External Uncertainty & $\begin{array}{c}0.078 * * * \\
(0.026)\end{array}$ & $\begin{array}{l}0.003 \\
(0.029)\end{array}$ & $\begin{array}{l}0.012 \\
(0.012)\end{array}$ & $\begin{array}{l}0.021 \\
(0.019)\end{array}$ \\
\hline Delegation - Control & - & $\begin{array}{c}0.348^{* *} \\
(0.158)\end{array}$ & $\begin{array}{c}0.024 \\
(0.100)\end{array}$ & $\begin{array}{l}-0.157 \\
(0.113)\end{array}$ \\
\hline Monitoring & - & - & $\begin{array}{l}0.103 \\
(0.085)\end{array}$ & $\begin{array}{l}0.088 \\
(0.138)\end{array}$ \\
\hline OJT & - & - & - & $\begin{array}{c}1.193 * * * \\
(0.261)\end{array}$ \\
\hline $\mathrm{Chi}^{2}$ & 67.98 & 29.19 & 28.60 & 26.77 \\
\hline
\end{tabular}




\begin{tabular}{||l||c|c|c|c||}
\hline \hline & $\begin{array}{c}\text { Individual } \\
\text { Delegation }\end{array}$ & Monitoring & $\begin{array}{c}\text { ILM - } \\
\text { Employment } \\
\text { Security }\end{array}$ & Group Bonus \\
\hline \hline Internal Uncertainty & $\begin{array}{c}0.035^{* * *} \\
(0.010)\end{array}$ & $\begin{array}{c}-0.155^{* * *} \\
(0.031)\end{array}$ & $\begin{array}{c}0.021 \\
(0.026)\end{array}$ & $\begin{array}{c}0.042 \\
(0.035)\end{array}$ \\
\hline
\end{tabular}

Table C2c: Uncertainty, Group Bonus, Monitoring and Internal Labor Market ${ }^{\mathrm{a}}$ 3SLS Estimations 


\begin{tabular}{|c|c|c|c|c|}
\hline External Uncertainty & $0.019 *$ & 0.007 & 0.018 & 0.051 \\
\hline Team Delegation & - & $\begin{array}{c}1.121 * * * \\
(0.433)\end{array}$ & $\begin{array}{c}-0.268 * * * \\
(0.232)\end{array}$ & $\begin{array}{c}0.617 * * * \\
(0.253)\end{array}$ \\
\hline Monitoring & - & - & $\begin{array}{l}0.123 \\
(0.097)\end{array}$ & $\begin{array}{l}-0.161 \\
(0.131)\end{array}$ \\
\hline Employment Security & - & - & - & $\begin{array}{c}0.890^{* * * *} \\
(0.210)\end{array}$ \\
\hline \multirow[t]{2}{*}{$\begin{array}{l}\mathrm{Chi}^{2} \\
\text { (p-value) }\end{array}$} & $\begin{array}{c}35.49 \\
(0.000)\end{array}$ & $\begin{array}{c}28.22 \\
(0.000)\end{array}$ & $\begin{array}{c}9.12 \\
(0.104)\end{array}$ & $\begin{array}{c}37.53 \\
(0.000)\end{array}$ \\
\hline & $\begin{array}{l}\text { Individual } \\
\text { Delegation }\end{array}$ & Monitoring & ILM - Promotions & Group Bonus \\
\hline Internal Uncertainty & $\begin{array}{c}0.034 * * * \\
(0.011)\end{array}$ & $\begin{array}{c}-0.153 * * * \\
(0.031)\end{array}$ & $\begin{array}{c}0.008 \\
(0.018)\end{array}$ & $\begin{array}{l}0.006 \\
(0.021)\end{array}$ \\
\hline External Uncertainty & $\begin{array}{l}0.019 * \\
(0.011)\end{array}$ & $\begin{array}{c}0.008 \\
(0.028)\end{array}$ & $\begin{array}{l}-0.006 \\
(0.012)\end{array}$ & $\begin{array}{l}0.013 \\
(0.017)\end{array}$ \\
\hline Team Delegation & - & $\begin{array}{c}1.065^{* * * *} \\
(0.433)\end{array}$ & $\begin{array}{l}0.282 \\
(0.212)\end{array}$ & $\begin{array}{l}0.225 \\
(0.248)\end{array}$ \\
\hline Monitoring & - & - & $\begin{array}{l}-0.011 \\
(0.089)\end{array}$ & $\begin{array}{c}0.054 \\
(0.132)\end{array}$ \\
\hline Promotions & - & - & - & $\begin{array}{c}0.682 * * * \\
(0.194)\end{array}$ \\
\hline \multirow[t]{2}{*}{$\begin{array}{l}\mathrm{Chi}^{2} \\
\text { (p-value) }\end{array}$} & $\begin{array}{c}39.00 \\
(0.000)\end{array}$ & $\begin{array}{c}27.47 \\
(0.000)\end{array}$ & $\begin{array}{l}11.56 \\
(0.041)\end{array}$ & $\begin{array}{l}30.15 \\
(0.000)\end{array}$ \\
\hline & $\begin{array}{l}\text { Individual } \\
\text { Delegation }\end{array}$ & Monitoring & $\begin{array}{c}\text { ILM - On the Job } \\
\text { Training }\end{array}$ & Group Bonus \\
\hline Internal Uncertainty & $\begin{array}{c}0.034 * * * \\
(0.011)\end{array}$ & $\begin{array}{c}-0.152 * * * \\
(0.031)\end{array}$ & $\begin{array}{l}-0.010 \\
(0.022)\end{array}$ & $\begin{array}{c}0.000 \\
(0.021)\end{array}$ \\
\hline External Uncertainty & $\begin{array}{l}0.019^{*} \\
(0.011)\end{array}$ & $\begin{array}{c}0.009 \\
(0.028)\end{array}$ & $\begin{array}{l}0.006 \\
(0.016)\end{array}$ & $\begin{array}{l}-0.000 \\
(0.016)\end{array}$ \\
\hline Team Delegation & - & $\begin{array}{c}1.057 * * \\
(0.432)\end{array}$ & $\begin{array}{c}0.812 * * * \\
(0.269)\end{array}$ & $\begin{array}{l}0.123 \\
(0.288)\end{array}$ \\
\hline Monitoring & - & - & $\begin{array}{c}-0.236^{* *} \\
(0.109)\end{array}$ & $\begin{array}{l}0.018 \\
(0.128)\end{array}$ \\
\hline Team Training & - & - & - & $\begin{array}{c}0.499 * * * \\
(0.204)\end{array}$ \\
\hline $\begin{array}{l}\mathrm{Chi}^{2} \\
\text { (p-value) }\end{array}$ & $\begin{array}{c}38.64 \\
(0.000)\end{array}$ & $\begin{array}{c}27.21 \\
(0.026) \\
\end{array}$ & $\begin{array}{c}35.57 \\
(0.000)\end{array}$ & $\begin{array}{c}26.19 \\
(0.000)\end{array}$ \\
\hline
\end{tabular}


Table C2d: Uncertainty, Cash Profit Sharing, Monitoring and Internal Labor Market ${ }^{\mathrm{a}}$ 3SLS Estimations

\begin{tabular}{|c|c|c|c|c|}
\hline & $\begin{array}{c}\text { Team } \\
\text { Delegation }\end{array}$ & Monitoring & $\begin{array}{c}\text { ILM - } \\
\text { Employment } \\
\text { Security } \\
\end{array}$ & $\begin{array}{c}\text { Cash Profit } \\
\text { Sharing }\end{array}$ \\
\hline Internal Uncertainty & $\begin{array}{c}0.034 * * * \\
(0.010)\end{array}$ & $\begin{array}{c}-0.154 * * * \\
(0.031)\end{array}$ & $\begin{array}{c}0.021 \\
(0.020)\end{array}$ & $\begin{array}{l}-0.015 \\
(0.023)\end{array}$ \\
\hline External Uncertainty & $\begin{array}{l}0.019 * \\
(0.011)\end{array}$ & $\begin{array}{c}0.007 \\
(0.028)\end{array}$ & $\begin{array}{l}0.018 \\
(0.014)\end{array}$ & $\begin{array}{l}-0.009 \\
(0.019)\end{array}$ \\
\hline Team Delegation & - & $\begin{array}{c}1.110^{* *} \\
(0.432)\end{array}$ & $\begin{array}{l}-0.260 \\
(0.234)\end{array}$ & $\begin{array}{c}0.959 \\
(0.258)\end{array}$ \\
\hline Monitoring & - & - & $\begin{array}{l}0.121 \\
(0.097)\end{array}$ & $\begin{array}{l}0.173 \\
(0.122)\end{array}$ \\
\hline Employment Security & - & - & - & $\begin{array}{l}0.155 \\
(0.208)\end{array}$ \\
\hline \multirow[t]{2}{*}{$\begin{array}{l}\mathrm{Chi}^{2} \\
\text { (p-value) }\end{array}$} & $\begin{array}{c}38.69 \\
(0.000)\end{array}$ & $\begin{array}{c}28.76 \\
(0.026)\end{array}$ & $\begin{array}{c}8.61 \\
(0.000)\end{array}$ & $\begin{array}{c}26.92 \\
(0.000)\end{array}$ \\
\hline & $\begin{array}{c}\text { Team } \\
\text { Delegation } \\
\end{array}$ & Monitoring & ILM - Promotions & $\begin{array}{c}\text { Cash Profit } \\
\text { Sharing } \\
\end{array}$ \\
\hline Internal Uncertainty & $\begin{array}{c}0.034 * * * \\
(0.010)\end{array}$ & $\begin{array}{c}-0.152 * * * \\
(0.031)\end{array}$ & $\begin{array}{c}0.008 \\
(0.018)\end{array}$ & $\begin{array}{l}-0.016 \\
(0.023)\end{array}$ \\
\hline External Uncertainty & $\begin{array}{l}0.019^{*} \\
(0.011)\end{array}$ & $\begin{array}{l}0.009 \\
(0.028)\end{array}$ & $\begin{array}{l}-0.005 \\
(0.012)\end{array}$ & $\begin{array}{l}-0.013 \\
(0.019)\end{array}$ \\
\hline Team Delegation & - & $\begin{array}{c}1.054 * * * \\
(0.431)\end{array}$ & $\begin{array}{l}0.307 \\
(0.213)\end{array}$ & $\begin{array}{c}1.086^{* * *} \\
(0.269)\end{array}$ \\
\hline Monitoring & - & - & $\begin{array}{l}-0.011 \\
(0.089)\end{array}$ & $\begin{array}{l}0.115 \\
(0.127)\end{array}$ \\
\hline Promotions & - & - & - & $\begin{array}{l}-0.287 \\
(0.190)\end{array}$ \\
\hline \multirow[t]{2}{*}{$\begin{array}{l}\mathrm{Chi}^{2} \\
\text { (p-value) }\end{array}$} & $\begin{array}{c}43.28 \\
(0.000) \\
\end{array}$ & $\begin{array}{c}27.64 \\
(0.000) \\
\end{array}$ & $\begin{array}{c}10.41 \\
(0.000) \\
\end{array}$ & $\begin{array}{c}30.38 \\
(0.000) \\
\end{array}$ \\
\hline & $\begin{array}{c}\text { Team } \\
\text { Delegation }\end{array}$ & Monitoring & $\begin{array}{c}\text { ILM - On the Job } \\
\text { Training }\end{array}$ & $\begin{array}{c}\text { Cash Profit } \\
\text { Sharing }\end{array}$ \\
\hline Internal Uncertainty & $\begin{array}{c}0.034 * * * \\
(0.010)\end{array}$ & $\begin{array}{c}-0.153 * * * \\
(0.031)\end{array}$ & $\begin{array}{l}-0.010 \\
(0.023)\end{array}$ & $\begin{array}{l}-0.014 \\
(0.023)\end{array}$ \\
\hline External Uncertainty & $\begin{array}{l}0.019^{*} \\
(0.011)\end{array}$ & $\begin{array}{c}0.008 \\
(0.028)\end{array}$ & $\begin{array}{l}0.006 \\
(0.016)\end{array}$ & $\begin{array}{l}-0.006 \\
(0.019)\end{array}$ \\
\hline Team Delegation & - & $\begin{array}{c}1.073 * * \\
(0.430)\end{array}$ & $\begin{array}{c}0.844 * * * \\
(0.270)\end{array}$ & $\begin{array}{c}1.105 * * * \\
(0.314)\end{array}$ \\
\hline Monitoring & - & - & $\begin{array}{c}-0.234 * * \\
(0.109)\end{array}$ & $\begin{array}{l}0.151 \\
(0.125)\end{array}$ \\
\hline Team Training & - & - & - & $\begin{array}{l}-0.170 \\
(0.200)\end{array}$ \\
\hline $\begin{array}{l}\mathrm{Chi}^{2} \\
\text { (p-value) }\end{array}$ & $\begin{array}{c}41.45 \\
(0.000) \\
\end{array}$ & $\begin{array}{c}27.97 \\
(0.026) \\
\end{array}$ & $\begin{array}{c}34.23 \\
(0.000) \\
\end{array}$ & $\begin{array}{c}27.84 \\
(0.000) \\
\end{array}$ \\
\hline
\end{tabular}


Table C2e: Uncertainty, Cash Profit Sharing, Monitoring and Internal Labor Market ${ }^{\mathrm{a}}$ 3SLS Estimations

\begin{tabular}{|c|c|c|c|c|}
\hline & $\begin{array}{l}\text { Individual } \\
\text { Delegation }\end{array}$ & Monitoring & $\begin{array}{c}\text { ILM - } \\
\text { Employment } \\
\text { Security }\end{array}$ & $\begin{array}{l}\text { Deferred } \\
\text { Profit } \\
\text { Sharing }\end{array}$ \\
\hline Internal Uncertainty & $\begin{array}{c}0.109 * * * \\
(0.028)\end{array}$ & $\begin{array}{c}-0.104 * * * \\
(0.029)\end{array}$ & $\begin{array}{l}-0.012 \\
(0.019)\end{array}$ & $\begin{array}{l}-0.035^{*} \\
(0.019)\end{array}$ \\
\hline External Uncertainty & $\begin{array}{l}0.001 \\
(0.029)\end{array}$ & $\begin{array}{l}0.030 \\
(0.025)\end{array}$ & $\begin{array}{l}0.016 \\
(0.014)\end{array}$ & $\begin{array}{c}-0.035^{* *} \\
(0.016)\end{array}$ \\
\hline Individual Delegation & - & $\begin{array}{c}-0.026^{* *} \\
(0.121)\end{array}$ & $\begin{array}{l}0.174 * \\
(0.106)\end{array}$ & $\begin{array}{c}0.265 * * * \\
(0.074)\end{array}$ \\
\hline Monitoring & - & - & $\begin{array}{l}0.112 \\
(0.094)\end{array}$ & $\begin{array}{c}0.004 \\
(0.113)\end{array}$ \\
\hline Employment Security & - & - & - & $\begin{array}{c}-0.385^{*} \\
(0.241)\end{array}$ \\
\hline \multirow[t]{2}{*}{$\begin{array}{l}\mathrm{Chi}^{2} \\
\text { (p-value) }\end{array}$} & $\begin{array}{c}58.54 \\
(0.000) \\
\end{array}$ & $\begin{array}{c}25.94 \\
(0.026) \\
\end{array}$ & $\begin{array}{c}14.37 \\
(0.000) \\
\end{array}$ & $\begin{array}{c}25.33 \\
(0.000) \\
\end{array}$ \\
\hline & $\begin{array}{l}\text { Individual } \\
\text { Delegation }\end{array}$ & Monitoring & ILM - Promotions & $\begin{array}{c}\text { Deferred } \\
\text { Profit Sharing }\end{array}$ \\
\hline Internal Uncertainty & $\begin{array}{c}0.113 * * * \\
(0.028)\end{array}$ & $\begin{array}{c}-0.104 * * * \\
(0.029)\end{array}$ & $\begin{array}{l}-0.013 \\
(0.019)\end{array}$ & $\begin{array}{l}-0.032^{*} \\
(0.018)\end{array}$ \\
\hline External Uncertainty & $\begin{array}{l}0.001 \\
(0.029)\end{array}$ & $\begin{array}{l}0.030 \\
(0.025)\end{array}$ & $\begin{array}{l}0.000 \\
(0.014)\end{array}$ & $\begin{array}{c}-0.041 * * \\
(0.016)\end{array}$ \\
\hline Individual Delegation & - & $\begin{array}{l}-0.026 \\
(0.121)\end{array}$ & $\begin{array}{l}0.331 * * * \\
(0.105)\end{array}$ & $\begin{array}{l}0.256 * * * \\
(0.077)\end{array}$ \\
\hline Monitoring & - & - & $\begin{array}{l}0.060 \\
(0.088)\end{array}$ & $\begin{array}{l}-0.021 \\
(0.116)\end{array}$ \\
\hline Promotions & - & - & - & $\begin{array}{l}-0.205 \\
(0.218)\end{array}$ \\
\hline \multirow[t]{2}{*}{$\begin{array}{l}\mathrm{Chi}^{2} \\
\text { (p-value) }\end{array}$} & $\begin{array}{c}51.62 \\
(0.000)\end{array}$ & $\begin{array}{c}25.06 \\
(0.000)\end{array}$ & $\begin{array}{c}27.10 \\
(0.000)\end{array}$ & $\begin{array}{c}26.26 \\
(0.000)\end{array}$ \\
\hline & $\begin{array}{l}\text { Individual } \\
\text { Delegation }\end{array}$ & Monitoring & $\begin{array}{c}\text { ILM - On the Job } \\
\text { Training }\end{array}$ & $\begin{array}{l}\text { Deferred } \\
\text { Profit } \\
\text { Sharing } \\
\end{array}$ \\
\hline Internal Uncertainty & $\begin{array}{c}0.109 * * * \\
(0.028)\end{array}$ & $\begin{array}{c}-0.104 * * * \\
(0.029)\end{array}$ & $\begin{array}{c}0.006 \\
(0.017)\end{array}$ & $\begin{array}{l}-0.036^{*} \\
(0.019)\end{array}$ \\
\hline External Uncertainty & $\begin{array}{c}0.001 \\
(0.029)\end{array}$ & $\begin{array}{l}0.031 \\
(0.025)\end{array}$ & $\begin{array}{l}0.015 \\
(0.012)\end{array}$ & $\begin{array}{c}-0.034 * * \\
(0.016)\end{array}$ \\
\hline Individual Delegation & - & $\begin{array}{l}-0.022 \\
(0.121)\end{array}$ & $\begin{array}{l}0.128 \\
(0.091)\end{array}$ & $\begin{array}{l}0.329 * * * \\
(0.094)\end{array}$ \\
\hline Monitoring & - & - & $\begin{array}{l}0.111 \\
(0.082)\end{array}$ & $\begin{array}{l}-0.022 \\
(0.115)\end{array}$ \\
\hline OJT & - & - & - & $\begin{array}{l}-0.507 \\
(0.291)\end{array}$ \\
\hline $\begin{array}{l}\mathrm{Chi}^{2} \\
\text { (p-value) }\end{array}$ & $\begin{array}{c}59.57 \\
(0.000) \\
\end{array}$ & $\begin{array}{c}24.81 \\
(0.026) \\
\end{array}$ & $\begin{array}{r}34.78 \\
(0.000) \\
\end{array}$ & $\begin{array}{c}26.37 \\
(0.000) \\
\end{array}$ \\
\hline
\end{tabular}

